\title{
Plants and Natural Products for the Treatment of Skin Hyperpigmentation - A Review
}

Authors

Mayuree Kanlayavattanakul ${ }^{1,2}$, Nattaya Lourith ${ }^{1,2}$

Affiliations

1 School of Cosmetic Science, Mae Fah Luang University, Chiang Rai, Thailand

2 Phytocosmetics and Cosmeceuticals Research Group, Mae Fah Luang University, Chiang Rai, Thailand

Key words

cosmeceuticals, hyperpigmentation, kojic acid, natural products, skin-whitening, topical agents

received November 13, 2017

revised February 10, 2018

accepted February 20, 2018

\author{
Bibliography \\ DOI https://doi.org/10.1055/a-0583-0410 \\ Published online March 5, 2018 | Planta Med 2018; 84: 988- \\ 1006 @ Georg Thieme Verlag KG Stuttgart · New York | \\ ISSN 0032-0943 \\ Correspondence \\ Nattaya Lourith \\ School of Cosmetic Science/Phytocosmetics and Cosmeceuti- \\ cals Research Group, Mae Fah Luang University \\ 333 Tasud, 57100 Chiang Rai, Thailand \\ Phone: + 6653916834 , Fax: + 6653916831 \\ nattayal@mfu.ac.th
}

\begin{abstract}
Skin hyperpigmentation is caused by several factors that upregulate melanogenesis. Plants and natural products with skin-whitening effects are gaining interest among consumers and researchers because they are perceived to be milder, safer, and healthier than synthetic alternatives. This review extensively summarizes the status of plants and natural products currently used in skin-whitening cosmetics as well as potential candidates for future use, because the scope of natural choices for efficient treatment of skin hyperpigmentation is rapidly widening. Biological activities of plants and natural extracts are therefore available for cosmetic formulators and dermatologists interested in naturally derived ingredients for skin hyperpigmentation treatment and in accordance with the consumers' preferences and expectations upon natural cosmetic products.
\end{abstract}

\section{Introduction}

Skin hyperpigmentation is caused by several factors (i.e., UV radiation, radicals, inflammatory mediators, and hormones) as depicted in $>$ Fig. 1. Briefly, UV radiation causes skin hyperpigmentation by stimulating keratinocytes to secrete $\alpha$-MSH, a small peptide hormone derived from proopiomelanocortin. Consequently, $\alpha$-MSH binds to MC1R expressed on melanocyte surfaces and thereafter induces melanogenesis via multiple signaling pathways resulting from CAMP, PKA, CREB, and MITF activity. MITF is a key transcription factor regulating the transcription of melanogenic enzymes (i.e., TYR, TRP-1, and TRP-2). In addition, UV radiation modulates Nrf2 and further activates MAPKs. MAPKs consist of three subtypes: stress-activated protein kinases/JNK, p38, and ERKs. JNK and p38 kinases are stimulated by pro-inflammatory cytokines and environmentally induced stresses such as exposure to UV irradiation, heat, and hydrogen peroxide, resulting in DNA damage. Melanogenesis is controlled by MAPKs, with MITF being activated by $\mathrm{p} 38$ phosphorylation. By contrast, ERK activation inhibits melanin synthesis by downregulating MITF expression [1].

Preliminary evaluation of skin-whitening agents is best achieved through in vitro assays including cell culture assessments. In this context, plant-based and naturally derived skinwhitening agents have been examined for their biological activities and safety. Scientific literature provided by the American Chemical Society, J-STAGE, Karger, ScienceDirect, Taylor and Francis, Thieme Medical, and Wiley-Blackwell publishers included those that are searchable using Google Scholar published from 1997 to 2017 and cosmetic suppliers' databases. The literatures were searched on active, activity, bio-based, cosmeceuticals, hyperpigmentation, herb, melanin, melanogenesis, melanoma, plant, natural product, skin-lightening, and skin-whitening. Only articles in the English language have been selected. Unclear botanical identification, inadequate or insufficient data in terms of 


$\begin{array}{ll}\text { ABBREVIATIONS } & \\ \text { ABTS } & \text { 2,2'-azino-bis(3-ethylbenzothaiazoline)-6- } \\ & \text { sulfonic acid } \\ \text { CREB } & \text { cAMP response element-binding protein } \\ \text { DPPH } & \text { 1,1-diphenyl-2-picrylhydrazyl } \\ \text { EC } 50 & \text { half maximum effective concentration } \\ \text { ERKs } & \text { extracellular signal-regulated kinases } \\ \text { FRAP } & \text { ferric reducing ability of plasma } \\ \text { IC } 50 & \text { inhibitory concentration at 50\% } \\ \text { IL-1 } \alpha & \text { interleukin-1 } \alpha \\ \text { JNK } & \text { c-Jun NH2-terminal kinases } \\ \text { LD } 50 & \text { median lethal dose } \\ \text { MAPKs } & \text { mitogen-activated protein kinases } \\ \text { MC1R } & \text { melanocortin 1 receptor } \\ \text { MITF } & \text { microphthalmia-associated transcription factor } \\ \alpha-M S H & \alpha \text {-melanocyte-stimulating hormone Nrf2 nuclear } \\ & \text { factor E2-related factor } 2 \\ \text { PDA } & \text { potato dextrose agar } \\ \text { PKA } & \text { protein kinase A } \\ \text { TNF- } \alpha & \text { tumor necrosis factor- } \alpha \\ \text { TRP } & \text { tyrosinase-related protein } \\ \text { TYR } & \text { tyrosinase } \\ \text { VEGFR-2 } & \text { vascular endothelial growth factor receptor-2 } \\ & \end{array}$

examination assays with controls, and details on the preparation of natural products are excluded as described in $\boldsymbol{\sim}$ Fig. $\mathbf{2}$. The above-mentioned criteria allowed selecting 77 eligible articles. The excluded literature does not satisfy the selection methodology. Natural products (plants, fungi, and marine organisms) that are potentially available for further in vivo assessments were therefore summarized based on their scientific names including their isolated pure compounds.

\section{Active Ingredients for Skin Hyperpigmentation Treatment}

Phenolics are the most widely used skin-whitening agents, and they are used as a single compound or in combination to achieve synergistic effects [2-4]. Of these, hydroquinone (1), vitamin C or ascorbic acid (2), arbutin (3), and kojic acid (4) as well as their derivatives are most commonly used. In addition, herbal extracts, for instance mulberry, artocarpus, and orchid extracts, are also widely known skin-whitening agents [5, 6].

Retinoids (or vitamin A) (5) stimulate cell turnover and promote rapid loss of melanin through epidermopoiesis. Tocotrienols are derivatives of vitamin $E$ that are composed of four homologues: $\alpha$-, $\beta$-, $\gamma^{-}$, and $\delta$-tocotrienols. Of these, $\delta$-tocotrienol (6) was demonstrated to inhibit melanin production in B16 melanomas by downregulating TYR, TRP-1, and TRP-2 [7, 8]. At a maximum concentration of $20 \mu \mathrm{M}, \delta$-tocotrienol reduced melanin content and inhibited reactive oxygen species production by $20 \%$ and $15 \%$, respectively. Moreover, its downregulating effects on TYR, MC1R, MITF, TRP-1, and TRP-2 expression were concentration-de- pendent. Mechanistically, the enhancement of ERK phosphorylation levels occurs via MAPK signaling [9].

Other compounds downregulate melanogenesis via different mechanisms. For example, the phenolics caffeic acid (7), ferulic acid (8), quercetin (9), and rutin (10) modulate Nrf2 activity. UVA-induced melanogenesis in B16F10 cells is suppressed by TYR inhibition; in particular, quercetin (9), rutin (10), caffeic acid (7), and ferulic acid (8) reduce melanin content and inhibit TYR at $\mathrm{IC}_{30}$ values of $7.8 \pm 1.4$ and $10.1 \pm 3.1 \mu \mathrm{M}$, respectively, $15.31 \pm$ 4.7 and $18.56 \pm 4.2 \mu \mathrm{M}$, respectively, $17.54 \pm 4.8$ and $24.1 \pm$ $6.2 \mu \mathrm{M}$, respectively, and $>30$ and $>30 \mu \mathrm{M}$, respectively. Furthermore, caffeic acid (7) and quercetin (9) markedly suppress 8-hydroxy-2'-deoxyguanosine formation following UV irradiation, resulting in decreased DNA damage and glutathione depletion. Additionally, exposure to caffeic acid and quercetin prior to UVA irradiation induces cellular defenses against oxidative stress [10].

Caffeic acid phenethyl ester (11) occurs naturally in plants and propolis, and it is bioactivated by TYR, generating derivatives that are cytotoxic to melanoma cells. In B16F10 melanoma cells, it potently suppresses tumor growth and neovascularization by preventing VEGFR-2 activation [11]. Caffeic acid phenethyl ester also effectively slows $\alpha$-MSH-stimulated melanin synthesis by suppressing TYR, TRP-1, TRP-2, and MITF expression [12].

Genkwanin (12) was observed to significantly decrease melanin production in B16F10 melanoma cells in a concentration-dependent manner. Conversely, treatment with apigenin-7-glucoside (13) and naringenin (14) significantly stimulated intracellular melanin production (42.12 and $43.03 \mu \mathrm{g} / 10^{6}$ cells, respectively) compared with the control $\left(23.93 \mu \mathrm{g} / 10^{6}\right.$ cells $)$ [13].

Hinokitiol (15) was found to be more potent in inhibitory activity against mushroom TYR than hydroquinone (1), resorcinol (16), hydroxyhydroquinone (17), kojic acid (4), ascorbic acid (2), and arbutin (3), which exhibit $I C_{50}$ values of $8.22 \times 10^{-6}, 5.15 \times 10^{-5}$, $1.45 \times 10^{-5}, \quad 2.37 \times 10^{-4}, \quad 2.85 \times 10^{-4}, \quad 6.40 \times 10^{-4}$, and $7.48 \times$ $10^{-3} \mathrm{M}$, respectively [14]. It was noncytotoxic toward Mel-Ab cells at a concentration of $10 \mu \mathrm{M}$. Furthermore, treatment with $0.1 \mu \mathrm{M}$ hinokitiol significantly reduced cellular melanin content, with the effect increasing in a concentration-dependent manner. MITF is also effectively suppressed by hinokitiol [15].

Rhododendrol (18), or 4-(4-hydroxyphenyl)-2-butanol, inhibits TYR activity in cultured human melanocytes in a concentrationdependent manner $\left(\mathrm{IC}_{50}=5.3 \mu \mathrm{M}\right)$. This result was in accordance with radiolabeling experiments in B16 melanoma cells, which revealed that TYR utilizes rhododendrol as a substrate in place of $L$ tyrosine. Furthermore, the presence of rhododendrol resulted in no detectable reactive oxygen species in the melanocytes [16].

Linoleic acid (19) and palmitic acid (20) have divergent effects on melanogenesis in B16F10 melanoma cells relative to the control. Linoleic acid (19) decreases cellular melanin levels (30\%), whereas palmitic acid (20) enhances melanogenesis (150\%) in a time-dependent manner. These activities are regulated by TYR activity. Specifically, linoleic acid (19) suppresses its enzymatic activity by $50 \%$, whereas palmitic acid (20) promotes its overexpression to $190 \%$. However, neither acid affected the activity of TRP-1 and TRP-2, suggesting that they affect melanogenic enzymatic activity in a posttranscriptional manner. Further examination of the cellular mechanism revealed that the presence of linoleic acid 


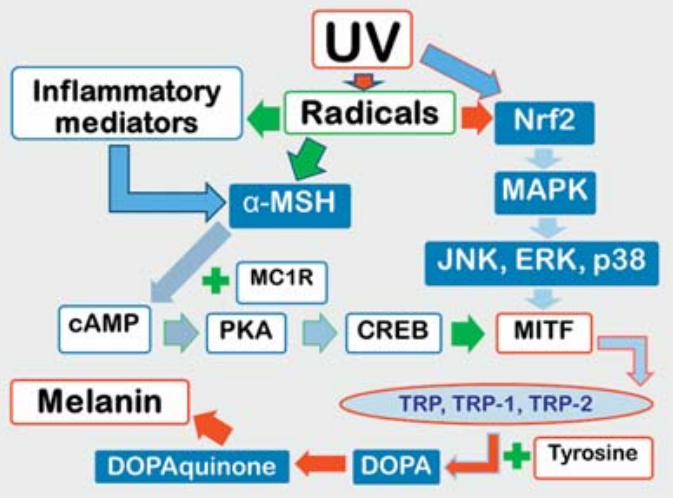

- Fig. 1 Mechanism of melanogenesis [1].

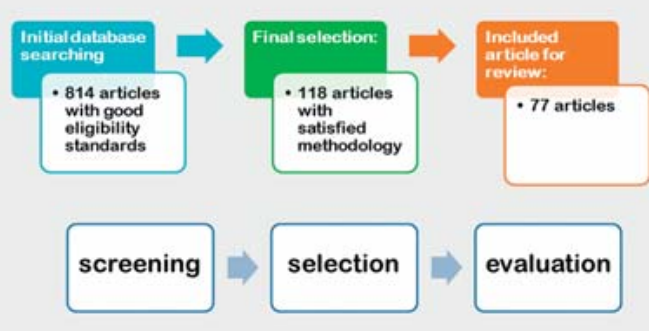

- Fig. 2 Criteria used to select the articles for the data presented in this review.

(19) decreases TYR levels to $30 \%$ of the initial level, whereas palmitic acid (20) markedly increased its content (130\% of the initial level). Radiolabeling assays indicated that linoleic acid (19) dramatically accelerates the proteolytic degradation of TYR compared with palmitic acid [17]. Linoleic acid (19) effectively modulates the proteasomal degradation of TYR via the selective degradation of a melanogenic enzyme through the ubiquitin-proteasome pathway [18].

A summary of the aforementioned compounds ( $\bullet$ Fig. 3 ), their activities, and other characteristics and properties is provided in - Table 1.

\section{Plants for Treating Skin Hyperpigmentation}

Treating aesthetically displeasing skin disorders using naturally derived agents including herbal extracts is gaining interest among consumers due to their perceived safety [2-4]. In this context, currently used herbs and those with potential skin-whitening effects are discussed.

Ten traditional Chinese herbs known to combat skin darkening were screened to identify their active components. Each herb was subjected to sequential soxhlet extraction using a range of solvents (i.e., hexane, $\mathrm{CH}_{2} \mathrm{Cl}_{2}$, $\mathrm{MeOH}$ ) featuring an increasing polar-
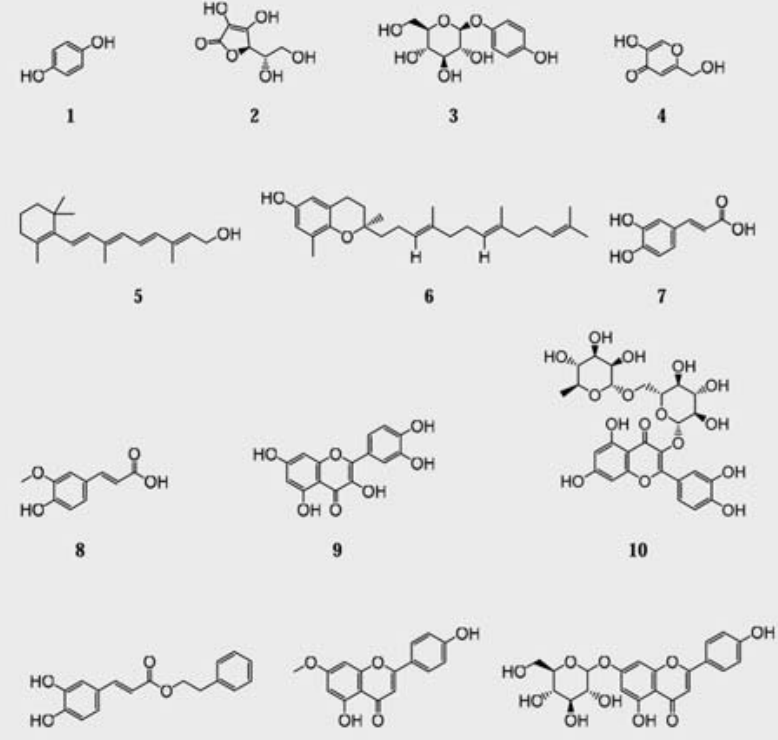

11

12

13

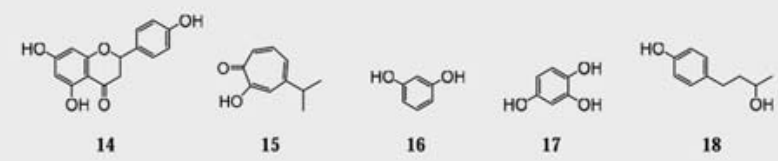

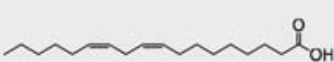

19
- Fig. 3 Chemical structures of the active ingredients for skin hyperpigmentation treatment.

ity gradient. Extraction was also conducted in parallel with boiling water. Following concentrating and drying, the extracts were tested in Melan-a cells, and hexane and dichloromethane extracts of Angelica sinensis (Oliv.) Diels Apiaceae exhibited the highest potency $\left(\mathrm{IC}_{50}=5.1\right.$ and $2.9 \mu \mathrm{g} / \mathrm{mL}$, respectively), in addition to being noncytotoxic. Other $A$. sinensis constituents, namely 4-ethylresorcinol (21), 4-ethylphenol (22), and 1-tetradecanol (23), were also active in the same assay, with $\mathrm{IC}_{50}$ values of $9.6,3.6$, and $19.37 \mu \mathrm{M}$, respectively [19].

Maceration of Arnica montana L. (Asteraceae) flowers in $80 \%$ EtOH followed by partitioning with EtOAc and chromatography afforded pure active 3 $3,16 \beta$-dihydroxy-21 $\alpha$-hydroperoxy-20 (30)-taraxastene (24). This compound is a potent melanogenesis inhibitor in B16 melanoma cells with an $\mathrm{IC}_{50}$ of $0.02 \mu \mathrm{g} / \mathrm{mL}$ $(0.04 \mu \mathrm{M})$, compared with $0.25 \mu \mathrm{g} / \mathrm{mL}(2.01 \mu \mathrm{M})$ for the positive control 4-methoxyphenol (25). Its inhibitory function is related to TRP-1 and MITF suppression [20].

Tarragon (Artemisia dracunculus L., Asteraceae), a commonly used flavoring herb, has been highlighted as a source of melanin biosynthesis inhibitors. Two isolated compounds, undeca-2E,4Edien,8,10-dynoic acid isobutylamide (26) and undeca-2E,4E-dien-8,10-dynoic acid piperidylamide (27), were found to be noncytotoxic toward B16 melanoma cells $\left(\mathrm{IC}_{50}=34.5\right.$ and $36.5 \mu \mathrm{g} / \mathrm{mL}$, 
- Table 1 Biological activities of active ingredients for skin hyperpigmentation treatment.

\begin{tabular}{|c|c|c|c|}
\hline \multirow[t]{2}{*}{ Name } & \multicolumn{2}{|l|}{ Study } & \multirow[t]{2}{*}{ Reference } \\
\hline & Enzyme inhibition & Cell culture & \\
\hline Vitamin $E(6)$ & & $\begin{array}{l}\text { TYR, TRP-1, and TRP-2 downrelations in B16F10 } \\
\text { MC1R, MITF downregulation } \\
\text { ERK phosphorylation enhancement }\end{array}$ & {$[7,8]$} \\
\hline Kojic acid (4) & mushroom TYR & TYR inhibitor & [9] \\
\hline Caffeic acid (7) & & TYR inhibition, DNA damage and glutathione depletion in B16F10 & [10] \\
\hline Caffeic acid phenyel ester (11) & & VEGFR-2, $\alpha$-MSH, TYR, TRP-1, TRP-2, and MITF suppression in B16F10 & {$[11,12]$} \\
\hline Ferulic acid (8) & & TYR inhibition, DNA damage and glutathione depletion in B16F10 & {$[10]$} \\
\hline Quercetin (9) & & TYR inhibition, DNA damage and glutathione depletion in B16F10 & [10] \\
\hline Rutin (10) & & TYR inhibition, DNA damage and glutathione depletion in B16F10 & [10] \\
\hline Genkwanin (12) & & antimelanogenesis in B16F10 & [13] \\
\hline Hinokitol (15) & mushroom TYR & cellular melanin production and MITF suppression in Mel-Ab & {$[14,15]$} \\
\hline
\end{tabular}

respectively) and to more potently suppress cellular melanin production ( $\mathrm{EC}_{50}=1.8$ and $2.3 \mu \mathrm{g} / \mathrm{mL}$, respectively) than arbutin $\left(E C_{50}=24.0 \mu \mathrm{g} / \mathrm{mL}\right)$. Their safety as skin-lightening agents was also confirmed, possessing safety coefficients $\left(E_{50} / I_{50}\right.$ ) of 19.2 and 12.9 , respectively [21].

Material from several Thai medicinal plants was macerated in EtOH, affording 77 crude extracts that were comparatively assessed for their inhibitory effects on mushroom TYR compared with standards kojic acid and Artocarpus lakoocha Roxb. (Moraceae) $(20 \mu \mathrm{g} / \mathrm{mL})$. A. lakoocha extract was the most potent inhibitor followed by kojic acid $(90.14 \% \pm 1.46 \%$ and $89.57 \% \pm 2.15 \%$, respectively), with root, root bark, and wood extracts of Artocarpus integer (Thunb.) Merr. (Moraceae) $(90.57 \% \pm 2.93 \%, 82.60 \%$ $\pm 0.76 \%$, and $80.02 \% \pm 3.22 \%$, respectively), wood extract of Cudrania javanensis Trec. (Moraceae) $(77.86 \% \pm 2.41 \%)$, and juice of Averrhoa bilimbi L. (Oxalidaceae) $(61.23 \% \pm 1.55 \%)$ also exerting potent inhibitory effects. $A$. integer root extract was further chromatographed, affording pure artocarpin (28), cudraflavone C (29), and artocarpanone (30), among which artocarpanone (30) was the most potent inhibitor, albeit with less potency than kojic acid (4) $\left(\mathrm{IC}_{50}=44.56\right.$ and $31.43 \mu \mathrm{g} / \mathrm{mL}$, respectively) [22]. In addition, Artocarpus xanthocarpus Merr. (Moraceae) root extracts provided artoxanthocarpone A (31) and chlorophorin (32), which proved to be more potent mushroom TYR inhibitors $\left(\mathrm{IC}_{50}=\right.$ $59.3 \pm 3.7$ and $2.5 \pm 0.4$, respectively) than arbutin (3) and kojic acid (4) $\left(\mathrm{IC}_{50}=81.8 \pm 2.3\right.$ and $63.7 \pm 4.5 \mu \mathrm{M}$, respectively). Assessments using B16F10 melanoma cells highlighted their safety (cell viability $=110.1 \% \pm 3.7 \%$ and $95.2 \% \pm 3.4 \%$ ) and abilities to suppress melanin production to $63.2 \% \pm 9.4 \%$ and $64.6 \% \pm 8.9 \%$ of the initial levels (at $40 \mu \mathrm{M}$ ), respectively. These results corresponded to more potent cellular TYR activities $(78.7 \% \pm 12.3 \%$ and $72.2 \% \pm 7.5 \%$, respectively) than those observed for $300 \mu \mathrm{M}$ arbutin (3) and kojic acid (4) $(76.4 \% \pm 6.3 \%$ and $85.8 \% \pm 6.8 \%$, respectively; $73.8 \% \pm 5.4 \%$ and $81.1 \% \pm 13.7 \%$, respectively) [23]. The skin-whitening effects of $A$. integer and Artocarpus heterophyllus Lam. (Moraceae) extracts were further confirmed with sapwood and heart wood extracts, which inhibited TYR activity $\left(\mathrm{IC}_{50}=7\right.$ and $125 \mu \mathrm{g} / \mathrm{mL}$, respectively). Later isolation studies indi- cated that their activity results from the presence of artocarpanone (30), as indicated by the mushroom TYR and melanin production activities in B16 melanoma cells $\left(\mathrm{IC}_{50}=80.8\right.$ and $89.1 \mu \mathrm{M}$, respectively) compared with those of arbutin- and kojic acid-treated cells (104 mM and $111 \mu \mathrm{M}$, respectively; 15.5 and $>3521 \mu \mathrm{M}$, respectively) [24].

Extraction of Betula pendula Roth (Betulaceae) leaves via homogenization in $80 \%$ EtOH afforded an extract containing substantial amounts of polymeric proanthocyanidins and phenolics. The crude extract inhibited mushroom TYR, albeit less potently than kojic acid (4) $\left(I C_{50}=119.08 \pm 2.04\right.$ and $2.24 \pm 0.18 \mu \mathrm{g} / \mathrm{mL}$, respectively) [25].

Methanol extract of sappanwood (Caesalpinia sappan L., Fabaceae) proved mildly effective in inhibiting melanin synthesis in B16F1 melanoma cells $(84.5 \% \pm 13.5 \%$ at $10 \mu \mathrm{g} / \mathrm{mL})$. The crude extract was further partitioned with hexane, EtOAc and $\mathrm{BuOH}$, giving different fractions that were subjected to the melanogenesis assay at the same concentration as the crude extract. The EtOAc fraction proved most potent, followed by the $\mathrm{BuOH}$ and hexane fractions $(79.4 \% \pm 9.0 \%, 78.3 \% \pm 20.1 \%$, and $0.3 \%$ $\pm 1.2 \%$, respectively). The EtOAc fraction was chromatographed, giving pure brazilin (33), 4-O-methylsappanol (34), brazilein (35), sappanchalcone (36), and 3'-deoxy-4-O-methylsappanol (37), all of which were more active $\left(I_{50}=3.0 \pm 0.5,4.6 \pm 0.7\right.$, $18.6 \pm 0.5,42.6 \pm 1.8$, and $50.4 \pm 2.0 \mu \mathrm{M}$, respectively) than kojic acid (4) $\left(\mathrm{IC}_{50}=70.6 \pm 3.0 \mu \mathrm{M}\right)$. Additionally, the compounds had more favorable cytotoxicity profiles $\left(\mathrm{IC}_{50}=18.4 \pm 0.8,20.2 \pm 0.8\right.$, $33.8 \pm 1.1,83.1 \pm 4.0$, and $72.0 \pm 2.4 \mu \mathrm{M}$, respectively) than kojic acid $(4)\left(\mathrm{IC}_{50}=99.7 \pm 2.1 \mu \mathrm{M}\right)[26]$.

Callicarpa longissima (Hemsl.) Merr., Verbenaceae leaf was extracted, affording a carnosol (38)-rich extract. This extract significantly suppressed melanin production in B16F10 melanoma cells, and its activity was associated with the downregulation of MITF gene transcription, diminishing TYR levels [27].

Safflower (Carthamus tinctorius L., Asteraceae) is the herbal source of the pigment carthamus yellow, which can suppress mushroom TYR in a concentration-dependent manner $\left(\mathrm{IC}_{50}=\right.$ $1.01 \pm 0.03 \mathrm{mg} / \mathrm{mL}$ ), although it is less potent than vitamin $C(2)$ 
$\left(I C_{50}=0.12 \pm 0.03 \mathrm{mg} / \mathrm{mL}\right)$. Kinetic analysis of the herbal extract revealed it to be a competitive TYR inhibitor, similar to arbutin (3), azelaic acid (39), deoxyarbutin (40), hydroquinone (1), and kojic acid (4). The phenolic compounds safflomin A (41) and safflomin B (42) are responsible for the activity of the herbal extract, both of which are noncytotoxic toward B16F10 melanoma cells at concentrations of $1-4 \mathrm{mg} / \mathrm{mL}$. At the highest concentration of $4 \mathrm{mg} / \mathrm{mL}$, melanin production was decreased to $82.3 \% \pm 0.4 \%$ of the initial level, whereas the effects of the extract were less pronounced in cells treated with $0.1 \mathrm{mg} / \mathrm{mL}$ vitamin C (2) or arbutin (3) $(87.9 \% \pm 1.6 \%$ and $56.8 \% \pm 1.7 \%$, respectively) [28]. $N$-feruloylserotonin (43), $\mathrm{N}$-( $p$-coumaroyl) serotonin (44), and acacetin (45) extracted from safflower seeds inhibited mushroom TYR with $I_{50}$ values of $0.023,0.074$, and $0.779 \mathrm{mM}$, respectively, compared with $0.223 \mathrm{mM}$ for arbutin (3). Their effects on melanin production and cytotoxicity in B16 melanoma cells were further examined, with the reduction in melanin content in accordance with the in vitro results. $\mathrm{N}$-feruloylserotonin (43), $\mathrm{N}$-( $p$-coumaroyl) serotonin (44), and acacetin (45) suppressed melanin production $\left({ }^{\prime} C_{50}=0.191,0.245\right.$ and $>20 \mathrm{mM}$, respectively) with $I C_{50}$ values of $>20,>20$, and $0.423 \mathrm{mM}$, respectively [29].

The inner skin of chestnut (Castanea crenata Siebold \& Zucc., Fagaceae) kernels boiled in aqueous $\mathrm{MeOH}$ solvent and then further partitioned with EtOAc afforded an extract for skin-whitening assessments. The EtOAc fraction inhibited mushroom TYR $\left(\mathrm{IC}_{50}=\right.$ $160 \mu \mathrm{g} / \mathrm{mL}$ ), and it was noncytotoxic toward B16F10 melanoma cells over the concentration range of $15-125 \mu \mathrm{g} / \mathrm{mL}$. The extract suppressed melanin production to $61.7 \%, 43.7 \%$, and $25.5 \%$ of the initial levels at concentrations of 10,50 , and $100 \mu \mathrm{g} / \mathrm{mL}$, respectively [30].

The phenolic-rich (17.4\% $\pm 0.67 \%$ ) extract of Chenopodium quinoa Willd., Chenopodiaceae or quinoa inhibited mushroom TYR activity at concentrations of 0.5 and $1.0 \mathrm{mg} / \mathrm{mL}(56.7 \%$ and $77.0 \%$, respectively; $p<0.001$ and $p<0.0001$, respectively), although it was less potent than kojic acid (4) (45.7\% at $0.01 \mathrm{mg} /$ $\mathrm{mL})[31]$.

Cocoloba uvifera L. (Polygonaceae) or Jamaican Kino or sea grape extract is an effective inhibitor of mushroom TYR, albeit to a lesser extent than kojic acid (4) $\left(\mathrm{IC}_{50}=90.4\right.$ and $20.2 \mu \mathrm{g} / \mathrm{mL}$, respectively). This extract also had anti-inflammatory properties, suppressing IL- $1 \alpha$ and TNF- $\alpha$ in UVB-stimulated melanocytes in a similar manner as kojic acid. Furthermore, it slowed the release of $\alpha$-MSH in melanocytes [32].

Colocasia antiquorum var. esculenta L. (Araceae), commonly known as Imperial Taro, is a source of biologically active fatty acids, sterols, and flavonoids. Its dried tuber bark was sonicated with $\mathrm{MeOH}$, partitioned with EtOAc, and chromatographed to isolate the active constituents in five fractions. Biologically active fractions were further purified to afford refined cis-grossamide $\mathrm{K}$ (46) and (-)-pinoresinol (47), exhibiting $I C_{50}$ values of 54.24 and $163.60 \mu \mathrm{M}$, respectively, and $\mathrm{LD}_{50}$ values of 556.26 and $>500 \mu \mathrm{M}$, respectively, as examined in Melan-a cells [33].

The aerial material of Crataegus azarolus L. (Rosaceae) macerated in $\mathrm{MeOH}$ for $10 \mathrm{~d}$ followed by further partitioning gave an EtOAc fraction containing ursolic acid (48), hyperoside (49), and virtexin-2"-O-rhamnoside (50) as major constituents. This fraction proved cytotoxic to B16F10 melanoma cells $\left(\mathrm{IC}_{50}=50 \mu \mathrm{g} /\right.$
$\mathrm{mL})$, and its application resulted in significant decreases in cellular melanin production at $50 \mu \mathrm{g} / \mathrm{mL}(\mathrm{p}<0.01)$ [34].

Extraction of saffron (Crocus sativus L., Iridaceae) petals with $\mathrm{MeOH}$, followed by partitioning and chromatography, afforded several pure compounds exhibiting mushroom TYR inhibitory activity. Crocusatin-K (51) displayed similar potency as kojic acid (4) $\left(\mathrm{IC}_{50}=260\right.$ and $250 \mu \mathrm{M}$, respectively), whereas crocusatin-L (52) and 4-hydroxy-3,5,5-trimethylcyclohex-2-enone (53) were less potent $\left(\mathrm{IC}_{50}=1.0\right.$ and $1.1 \mathrm{mM}$, respectively) [35].

Cudrania tricuspidata (Carrière) Bur. ex Lavallée (Moraceae) extract containing oxyresveratrol (54) and trans-dihydromorin (55) exhibited inhibitory effects against cellular melanin production in Melan-a cells. The safety margin of trans-dihydromorin was wider $(10-100 \mu \mathrm{M})$ than that of oxyresveratrol (54) (10-20 $\mu \mathrm{M})$. Its antimelanogenic effects resulted from MITF, TRP-1, and TRP-2 suppression, with oxyresveratrol (54) being less potent than trans-dihydromorin (55) [36].

The rhizome of nut grass, or purple nutsedge (Cyperus rotundus L., Cyperaceae), has been used in Oriental medicine due to its broad spectrum of activity against inflammation and cellular oxidation and proliferation. Extraction of the material afforded pure valencene (56), camphene (57), caryophyllene oxide (58), $\alpha$-cyperone (59), and nootkatone (60), with valencene (56) proving the strongest inhibitor of photoaging-related ion channels, as examined in HEK293T cells. Investigation of its antimelanogenic effects in UV-induced B16F10 cells confirmed that the mechanism of action involved ion channels and not the suppression of TYR activity [37].

Euterpe oleraceae Mart. (Arecaceae), commonly called açaí palm, oil contains oleic (61), palmitic (20), linoleic (19), palmitoleic (62), stearic (63), and linolenic (64) acids (60.7\%, $22.8 \%$, $9.6 \%, 4.2 \%, 1.9 \%$, and $0.3 \%$, respectively), and it has been revealed to inhibit mushroom TYR (IC $\left.\mathrm{I}_{50}=66.08 \mu \mathrm{g} / \mathrm{mL}\right)$, albeit less effectively than kojic acid $(4)\left(\mathrm{IC}_{50}=5.86 \mu \mathrm{g} / \mathrm{mL}\right)$ [38].

Soxhlet extraction of Garcinia livingstonei T. Anderson (Clusiaceae) stem bark gave a crude extract that was further purified by chromatography. One isolated compound, morelloflavone-7"-sulphate (65), was assayed in MeWo melanoma cells and identified as the most promising active compound in the bark fraction concerning cytotoxicity and suppression of melanin production $\left(\mathrm{IC}_{50}=41.8 \pm 2.5 \mu \mathrm{M}\right.$ and $\left.\mathrm{EC}_{50}=8.6 \pm 1.3 \mu \mathrm{M}\right)[39]$.

The aerial foliage of ground ivy (Glechoma hederacea L., Lamiaceae) was centrifuged in water, giving a clear supernatant that was subsequently lyophilized to afford a dry extract. The extract inhibited melanin production in B16F10 melanoma cells without inducing cytotoxicity at concentrations of $0.1-1 \mathrm{mg} / \mathrm{mL}$, with TYR inhibition occurring through MITF protein expression opposed to TRP-1 and TRP-2 [40].

Methanol extraction of Juniperus chinensis L. (Cupressaceae) yielded an extract exhibiting antioxidative scavenging (DPPH, $\left.\mathrm{IC}_{50}=9.45 \pm 0.07 \mu \mathrm{g} / \mathrm{mL}\right)$ and anti-TYR activities $\left(\mathrm{IC}_{50}=55.18 \pm\right.$ $0.55 \mu \mathrm{g} / \mathrm{mL}$ ). $\alpha$-MSH inhibition $\left(\mathrm{IC}_{50}=13.67 \mu \mathrm{g} / \mathrm{mL}\right.$ ) in B16F10 melanoma cells was also evident, with further examination of the extract resulting in the isolation of two antimelanogenic compounds, namely cedrol (66) and widdrol (67). In pure form $(10 \mu \mathrm{g} / \mathrm{mL})$, each agent more significantly $(p<0.05)$ inhibited cel- 
lular TYR activity and protein expression than arbutin (3) $(100 \mu \mathrm{g} /$ $\mathrm{mL})[41]$.

Extraction of the rhizome material of Kaempferia pandurate Roxb., Zingiberaceae, a traditional Thai herb, using EtOH followed by partitioning with EtOAc afforded a crude mother liquor that yielded panduratin A (68) on chromatography. Panduratin A (68) more potently inhibited melanin production in Melan-a cells than kojic acid (4) or arbutin (3) $\left(\mathrm{IC}_{50}=9.6,152\right.$ and $990 \mu \mathrm{M}$, respectively) in conjunction with anti-TYR effects $\left(I_{50}=8.2,126\right.$ and $660 \mu \mathrm{M}$, respectively). This noncytotoxic agent $\left(I_{50}=31.6 \mu \mathrm{M}\right)$ effectively suppressed TYR, TRP-1, and TRP-2 expression [42].

Litchi (Litchi chinensis Sonn., Sapindaceae) pericarp macerated in $70 \% \mathrm{EtOH}$ and partitioned gave rise to an EtOAc fraction, exhibiting significantly greater antioxidant activity than ascorbic acid $(\mathrm{p}<0.01)$, as assessed by ABTS $\left(\mathrm{IC}_{50}=7.137 \pm 0.021 \mu \mathrm{g} / \mathrm{mL}\right)$, DPPH $\left(\mathrm{IC}_{50}=2.288 \pm 0.063 \mu \mathrm{g} / \mathrm{mL}\right), \quad \mathrm{O}_{2}{ }^{\cdot-}$ scavenging $\quad\left(\mathrm{IC}_{50}=29.57 \pm\right.$ $0.30 \mu \mathrm{g} / \mathrm{mL})$, and FRAP $\left(\mathrm{EC}_{1 \mathrm{mMFeSO}}=8,013.183 \pm 58.804 \mu \mathrm{g} / \mathrm{mL}\right)$ assays. The extract exerted an in vitro TYR-suppressing effect $\left(I C_{50}=197.860 \pm 1.230 \mu \mathrm{g} / \mathrm{mL}\right)$. Litchi extract, being more potent than kojic acid (4), suppressed melanin production in B16F10 melanoma cells by inhibiting TYR and TRP-2. Quercetin (9), rosmarinic acid (69), and gallic acid (70) were the main active phenolics in the extract $[43,44]$.

Mulberry (Morus alba L., Moraceae) is widely used to treat skin hyperpigmentation due to its high phenolic content, particularly the active compound oxyresveratrol (54). Mulberrosides are other active compounds isolated from mulberry, with mulberroside $F$ (71) exhibiting more potent activity against mushroom TYR than kojic acid (4) $\left(\mathrm{IC}_{50}=0.29\right.$ at $\left.1.30 \mu \mathrm{g} / \mathrm{mL}\right)$, although its activity against mammalian TYR is weaker $\left(\mathrm{IC}_{50}=68.3\right.$ at $\left.58.5 \mu \mathrm{g} / \mathrm{mL}\right)$ [45]. Accordingly, mulberry extract is widely used in topical products for treating skin hyperpigmentation. Extracts of the closely related black or wild mulberry (Morus nigra L., Moraceae) leaf also inhibit mushroom TYR. The compounds responsible for the activity are isoquercitrin (72), rutin (10), and chlorogenic acid (73). The extract proved noncytotoxic toward B16F10 melanoma cells and human keratinocytes at $7.81 \mu \mathrm{g} / \mathrm{mL}$, its $I_{50}$ against mushroom TYR [46].

Nutmeg (Myristica fragrans Houtt., Myristicaceae) oil has long been used as a traditional medicine with well-known therapeutic effects. Partitioning of its ethanolic extract with EtOAc and chromatography afforded the melanogenesis inhibitor macelignan (74), which inhibits melanin production and exerts anti-TYR effects in Melan-a cells with $\mathrm{IC}_{50}$ values of 13 and $30 \mu \mathrm{M}$, respectively. This noncytotoxic compound functions by downregulating TYR, TRP-1, and TRP-2 (10-50 $\mu \mathrm{M})$, with TRP-2 being the most responsive to the compound [47]. In addition, another nutmeg-derived active safrole (75) inhibits the monophenolase and diphenolase activities of mushroom TYR $\left(I_{50}=32.11\right.$ and $27.32 \mu \mathrm{M}$, respectively) [48].

Naringi crenulata (Roxb.) D. H. Nicolson (Rutaceae), synonyms Hesperethusa crenulata M. Roem. (Rutaceae) or Limonia crenulata Roxb. (Rutaceae), is commonly called Kra-jae in Thai or Thanaka in Burmese. This herb has been continuously documented as a traditional cosmetic for its skin-whitening effects. Its extract inhibits mushroom TYR $\left(\mathrm{IC}_{50}=0.546 \mathrm{mg} / \mathrm{mL}\right)$ [49] due to its active components arbutin (3) and kojic acid (4) [50,51].
Rambutan (Nephelium lappaceum L., Sapindaceae) peel extract exhibited antioxidant activities as assessed by ABTS, DPPH, and $\mathrm{O}_{2}{ }^{--}$scavenging assays and inhibitory effects on mushroom TYR with $\mathrm{IC}_{50}$ values of $2.92 \pm 0.02,1.86 \pm 0.06,39.49 \pm 0.52$, and $430.84 \pm 0.57 \mu \mathrm{g} / \mathrm{mL}$, respectively. This noncytotoxic herbal extract suppressed melanin production in B16F10 melanoma cells was by inhibiting TYR and TRP-2. Ferulic acid (8) was reported to be the most prevalent phenolic in the extract followed by gallic acid (70), rosmarinic acid (69), caffeic acid (7), kojic acid (4), quercetin (9), and chlorogenic acid (73) [44, 52].

The panicle or flower of Jamine rice (Oryza sativa cv. indica, Oryzeae) has been shown to have a high content of $p$-coumaric (76), ferulic (8), and caffeic (7) acids. The extract did not show any cytotoxicity. It suppressed melanogenesis through TYR and TRP-2 inhibitions in B16F10 melanoma cells at a concentration of $0.1 \mathrm{mg} / \mathrm{mL}$. To determine the safety profile and antioxidant activity of the extract in human skin fibroblast cells, the extract was tested in a concentration range that was similar to the concentrations used in B16F10 cells $(0.0001-0.1 \mathrm{mg} / \mathrm{mL})$. The cellular antioxidant activity was dose-dependent due to its protecting effect from oxidative stress [53].

The skin depigmentation effects of Paeonia lactiflora Pall. (Paeoniaceae) root extract were assessed in comparison with its pure active compound paeoniflorin (77). HPLC analysis of P. lactiflora extract indicated the presence of $53.25 \%$ paeoniflorin (77). Reconstructed human pigmented epidermis was topically treated with P. lactiflora extracts (300 and $500 \mu \mathrm{g} / \mathrm{mL}$ ), paeoniflorin (77) $(120$ and $200 \mu \mathrm{g} / \mathrm{mL}$ ), and the positive control 4-n-butylresorcinol (50 and $83 \mu \mathrm{g} / \mathrm{mL}$ ). The cellular melanin content was significantly lower following treatment with the extract (28 and 30\%) or paeoniflorin (77) (30 and 10\%) than that obtained with the control (7\% and $26 \%$ ), as indicated by the melanin density determined via multiphoton microscopic analysis. P. lactiflora extract, paeoniflorin (77) (120 and $200 \mu \mathrm{g} / \mathrm{mL})$, and 4-n-butylresorcinol reduced melanin content by $23 \%$ and $39 \%$, respectively, $23 \%$ and $27 \%$, respectively, and $24 \%$ and $40 \%$, respectively [54].

Extraction of passion fruit (Passiflora edulis Sims, Passifloraceae) seeds using $80 \%$ EtOH afforded an extract rich in phenolics (total phenolic content $=33 \%)$ that significantly $(p<0.01)$ inhibited melanogenesis in MNT-1 human melanoma cells at a concentration of $20 \mu \mathrm{g} / \mathrm{mL}$. LC/MS studies identified the major active constituent $(4.8 \mathrm{mg} / \mathrm{g})$ as piceatannol $(78)$, with resveratrol (79) being a minor constituent $(0.22 \mathrm{mg} / \mathrm{g})$ [55]. Fractionation of the methanolic extract into the EtOAc fraction revealed that chlorogenic acid (73), rosmarinic acid (69), and quercetin (9) were the major phenolic constituents. The fraction with potent antioxidant activities $\left(\mathrm{IC}_{50 \mathrm{DPPH}}=2.7 \pm 0.2 \mu \mathrm{g} / \mathrm{mL}, \mathrm{IC}_{50 \mathrm{ABTS}}=9.0 \pm 0.0 \mu \mathrm{g} / \mathrm{mL}\right.$, and $\left.\mathrm{EC}_{1 \mathrm{mM} \text { FeSO4}}=2813.9 \pm 11.6\right)$ also inhibited TYR activity $(39.9 \% \pm 0.0 \%$ at $1 \mathrm{mg} / \mathrm{mL})$, and it was safe in Vero cells. The passion fruit seed extract was similarly protective against sun exposure as benzophenone-3, octylmethoxycinnamate and ferulic acid [56]. The extract was thereafter formulated into stable protective products (i.e., liquid foundation and concealer mousse covering UVA and UVB ranges) [57].

Phyla nodiflora (L.) Greene, Verbenaceae (frog fruit) is a common ingredient of herbal tea found in Taiwan. Dried aerial components of this herb macerated in $\mathrm{MeOH}$ followed by partitioning 
and chromatography afforded pure eupafolin (80), a flavonoid that is noncytotoxic towards B16F10 melanoma cells $(20-80 \mu \mathrm{M}$, $70-90 \%$ cell viability). At 5-10 $\mu \mathrm{M}$, cell viability exceeded $90 \%$; in this range, eupafolin $(80)$ significantly $(p<0.05)$ decreased cellular melanin production as well as TYR and MITF activities. TRP-1 was also significantly suppressed at $10 \mu \mathrm{M}$, with TRP-2 and p-CREB protein expression being significantly reduced at $0.1,1$ and $10 \mu \mathrm{M}$. Furthermore, at $10 \mu \mathrm{M}$, this herbal active regulates MAPK signaling to inhibit melanogenesis [58].

The ethanolic extract of Pinus tabulaeformis Carr. (Pinaceae), commonly called Pini Nodi Lignum, exhibited similar inhibitory effects on mushroom TYR $(51.7 \% \pm 9.1 \%$ at $10 \mu \mathrm{g} / \mathrm{mL})$ as arbutin (3) $(43.4 \% \pm 7.3 \%$ at $1 \mathrm{mM})$. The extract at $10 \mu \mathrm{g} / \mathrm{mL}$ suppressed melanin production by $52 \%(\mathrm{p}<0.05)$ in HM3KO melanoma cells compared with untreated cells. The molecular mechanism was found to involve the suppression of TYR and TRP-1 [59].

An extract of Punica granatum L. (Punicaceae) or pomegranate peel enriched with $20 \%$ punicalgin (81) significantly suppressed cellular melanin content by $40 \%$ and $60 \%$ at 50 and $100 \mu \mathrm{g} / \mathrm{mL}$, respectively, with no cytotoxic effects observed in Melan-a cells. Its antimelanogenic activity results from the potent suppression of TRP-1, TYR, and MC1R expression [60].

Acid hydrolysis of the aqueous ethanolic extract of Rhodiola rosea L. (Crassulaceae) root yielded several active principles, namely salidroside (82) and tyrosol (83), at levels of $0.28 \pm 0.03$ and $14.25 \pm 0.27 \mathrm{mg} / \mathrm{g}$, respectively. These agents inhibited TYR $(77.1 \% \pm 0.5 \%$ at $4 \mathrm{mg} / \mathrm{mL}$ ) more efficiently than arbutin (3) $(63.1 \% \pm 3.2 \%$ at $2 \mathrm{mM})$. B16F0 cell viability was maintained $(73.4 \% \pm 0.8 \%)$ following treatment with the most concentrated hydrolysate $(70 \mu \mathrm{g} / \mathrm{mL})$. Hydrolysate $(50 \mu \mathrm{g} / \mathrm{mL})$ suppressed melanin production similarly as arbutin (3). In addition, isolated tyrosol $(83)$ significantly $(p<0.001)$ inhibited melanin synthesis at 0.4 and $4 \mathrm{mM}$, with the inhibitory effect arising from activity against MITF and TRP-2 [61].

Material from Rhus verniciflua Stokes (Anacardiaceae), synonym Toxicodendron vernicifluum (Stokes) F. A. Barkley (Anacardiaceae), also known as the Chinese lacquer tree, produced a crude extract $(1 \mathrm{mg} / \mathrm{mL}$ ) on sonication with $80 \% \mathrm{EtOH}$ that completely inhibited TYR (100\% $\pm 10.95 \%)$. Cytotoxicity testing in B16F1 melanoma cells indicated that the extract was safe at $\leq 100 \mu \mathrm{g} / \mathrm{mL}$. Cellular melanin levels following treatment with 10,50 , and $100 \mathrm{\mu g} / \mathrm{mL}$ extract were $175.08 \% \pm 7.42 \%, 79.96 \% \pm 3.51 \%$, and $46.30 \% \pm 8.81 \%$, respectively, of the control level, with the inhibitory action due to TYR and MITF suppression [62].

Chia (Salvia hispanica L., Lamiaceae) seed extract containing $0.5 \%$ linoleic acid (19) and $1.2 \%$ linolenic acid (64) inhibited melanin production to $55 \%$ and $65 \%$ of the initial levels in Melan-a cells at 100 and $400 \mu \mathrm{g} / \mathrm{mL}$, respectively, with no effects on cell viability. This inhibitory effect was regulated by the suppression of TRP-1 and TYR, with MC1R expression being less affected at extract concentrations of 25 and $50 \mu \mathrm{g} / \mathrm{mL}$ [60].

Sage (Salvia officinalis L., Lamiaceae), similar as oregano, is a common source of therapeutic essential oil. Extraction with $\mathrm{MeOH}$ followed by partitioning and chromatography enabled isolation of 7a-methoxyrosmanol (84) and isorosmanol (85), which proved noncytotoxic toward B16 melanoma cells and suppressed melanin production $(93.5 \% \pm 13.6 \%$ and $65.3 \% \pm 9.5 \%$ at $20 \mu \mathrm{g} /$
$\mathrm{mL}$, and $105.3 \% \pm 3.0 \%$ and $50.4 \% \pm 4.5 \%$ at $10 \mu \mathrm{g} / \mathrm{mL}$, respectively) [63].

Maceration of Saururus chinensis (Lour.) Baill. (Saururaceae) foliage in $\mathrm{MeOH}$ yielded a crude extract exerting no cytotoxic effects in B16F10 cells $(1-500 \mathrm{mg} / \mathrm{mL})$. The inhibitory effect of the extract $(100-500 \mathrm{ng} / \mathrm{mL}$ ) against cellular melanin production was comparable to that of arbutin $(200 \mu \mathrm{M})$, and significant inhibition of cellular TYR $(50-500 \mathrm{ng} / \mathrm{mL})$ was observed. The mechanism of these effects was related to MITF and TYR downregulation via ERK activation [64].

Sesamol (86) isolated from sesame (Sesamun indicum L., Pedaliaceae) oil exhibits antioxidant and anti-TYR activities. The DPPHscavenging activity of sesamol $(86)\left(\mathrm{IC}_{50}=5.44 \mu \mathrm{g} / \mathrm{mL}\right)$ was comparable to that of butylated hydroxyl toluene $\left(\mathrm{IC}_{50}=5.81 \mu \mathrm{g} / \mathrm{mL}\right)$. Sesamol (86) is a powerful inhibitor of mushroom TYR, acting against the monophenolase activity of the enzyme $\left(\mathrm{K}_{\mathrm{i}}=1.4 \mu \mathrm{M}\right.$, $\left.\mathrm{IC}_{50}=3.2 \mu \mathrm{M}\right)$ through complex formation. This activity proved more potent than that of kojic acid (4) $\left(\mathrm{IC}_{50}=59.72 \mu \mathrm{M}\right)$, and it was consistent with its inhibitory effects against melanin production in B16F10 melanoma cells $(63 \%$ at $100 \mu \mathrm{g} / \mathrm{mL})$ [65]. The compound was also more potent than kojic acid (4) in SK-MEL2 cells $(23.55 \% \pm 8.25 \%$ at $217 \mu \mathrm{M}$ and $33.88 \% \pm 1.43 \%$ at $4222 \mu \mathrm{M})$ and arbutin (3) $(8.26 \% \pm 8.78 \%$ at $3673 \mu \mathrm{M})[66]$.

The inner bark of Tabebuia avellanedae Lorentz ex Griseb. (Bignoniaceae), synonym Handroanthus impetiginosus (Mart. ex DC.) (Mattos), or pink lapacho, contains $\beta$-lapachone (87), which proved noncytotoxic toward Melan-a cells (concentration range, $0.2-0.8 \mu \mathrm{M}$ ) and displayed significant reducing effects on melanin content at $0.8 \mu \mathrm{M}$. Cellular TYR activity was depressed by $60 \%$ at this concentration, and this effect was regulated by MITF inhibition. Moreover, reductions in the mRNA levels of TYR, TRP-1, and TRP-2 (but not MITF and mRNA) were detected, in addition to delayed phosphorylation of ERK in Melan-a cells. Examinations in a human skin model (MelanoDerm) indicated the highest efficacy at a concentration of $40 \mu \mathrm{M}$ [67].

Sweet tamarind (Tamarindus indica L., Fabaceae) seed coat, with antioxidant activities according to ABTS, $\mathrm{DPPH}$, and $\mathrm{O}_{2}{ }^{-}$ scavenging assays and mushroom TYR activity $\left(\mathrm{IC}_{50}=3.41 \pm\right.$ $0.03,1.44 \pm 0.01,27.44 \pm 0.09$, and $96.15 \pm 0.62 \mu \mathrm{g} / \mathrm{mL}$, respectively), is a potential candidate herbal extract for skin hyperpigmentation treatment. In addition, the extract inhibited melanogenesis via inhibitory effects on TYR and TRP-2, as examined in B16F10 melanoma cells, due to its active compounds (-)-epicatechin (88), epigallocatechin (89), chlorogenic acid (73), quercetin (9), gallic acid (70), rosmarinic acid (69), caffeic acid (7), and ferulic acid (8) [44,68].

Cocoa (Theobroma cacao L., Sterculiaceae) powder was extracted with $80 \% \mathrm{EtOH}$, giving a crude extract that was assayed for mushroom TYR inhibition, affording an $\mathrm{IC}_{50}$ of $357.95 \mu \mathrm{g} / \mathrm{mL}$, which was superior to those of kojic acid (4) and arbutin (3) $\left(\mathrm{IC}_{50}=572.28\right.$ and $670.82 \mu \mathrm{g} / \mathrm{mL}$, respectively). This activity is related to the presence of phenolics and fatty acids, as characterized by LC/MS/MS [69].

The traditional Asian herbal cocktail Ssanghwa-tang, which contains the medicinal herbs P. lactiflora (28\%), Angelica gigas Nakai (Apiaceae) (11.2\%), Astragalus membranaceus (Fisch.) Bunge (Fabaceae) (11.2\%), Cnididium officinale Makino (Apiaceae) 


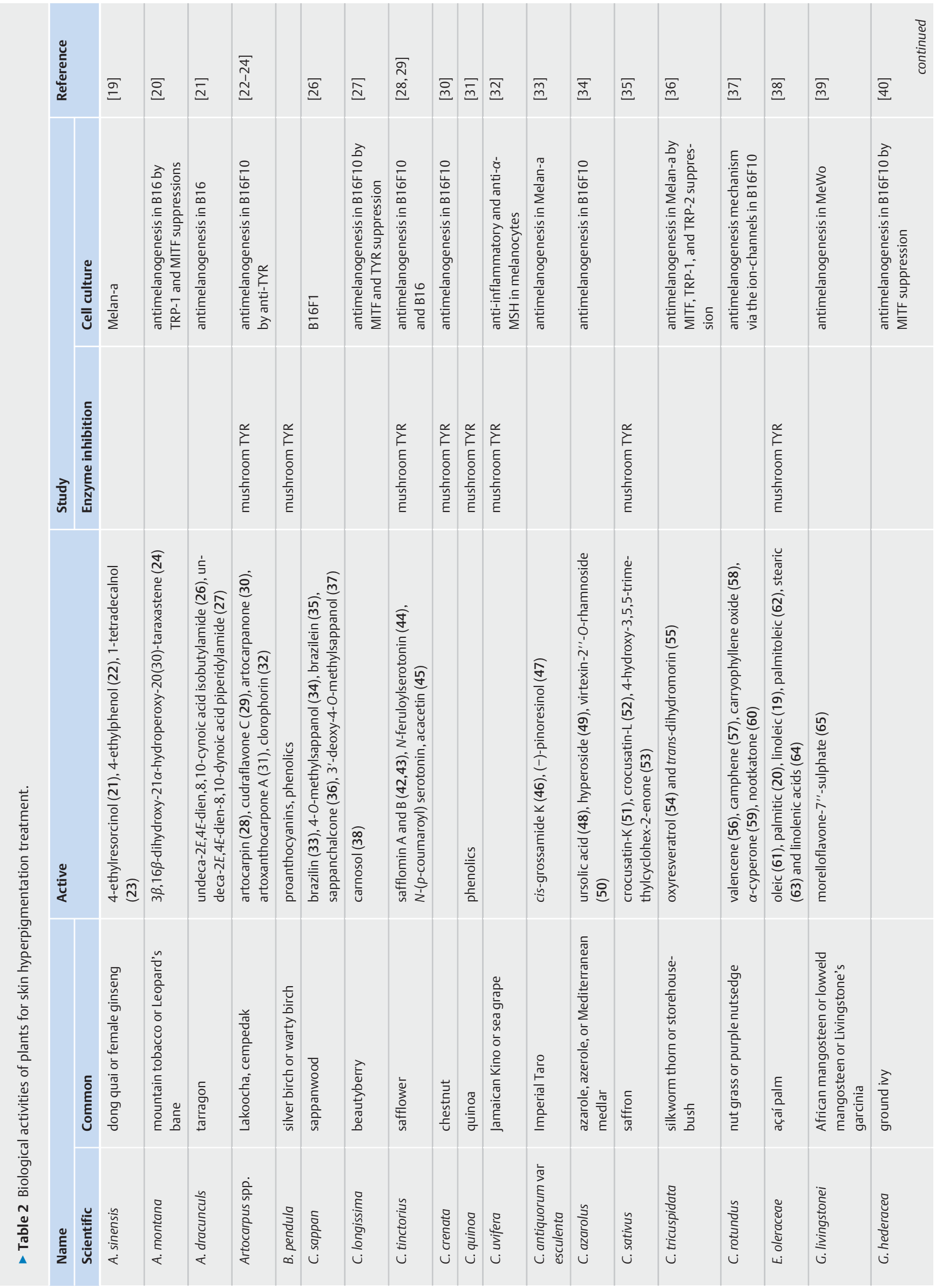

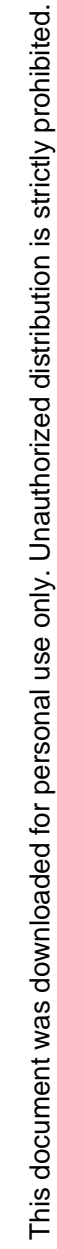




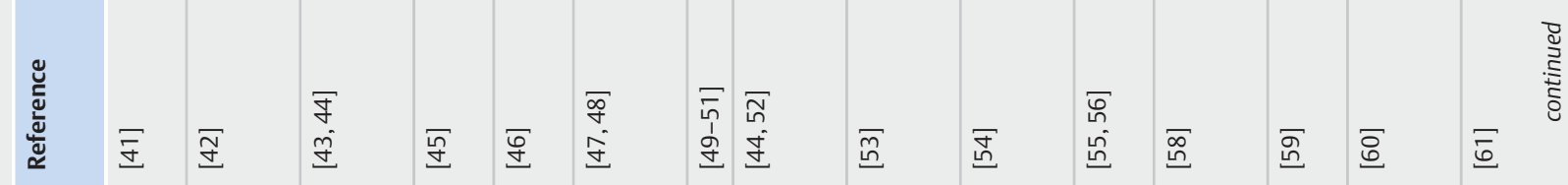

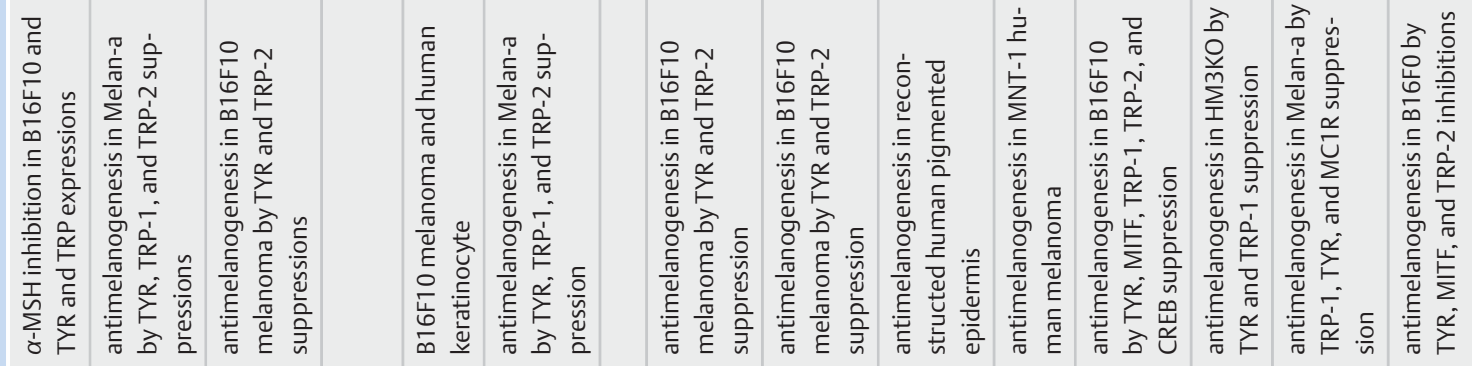
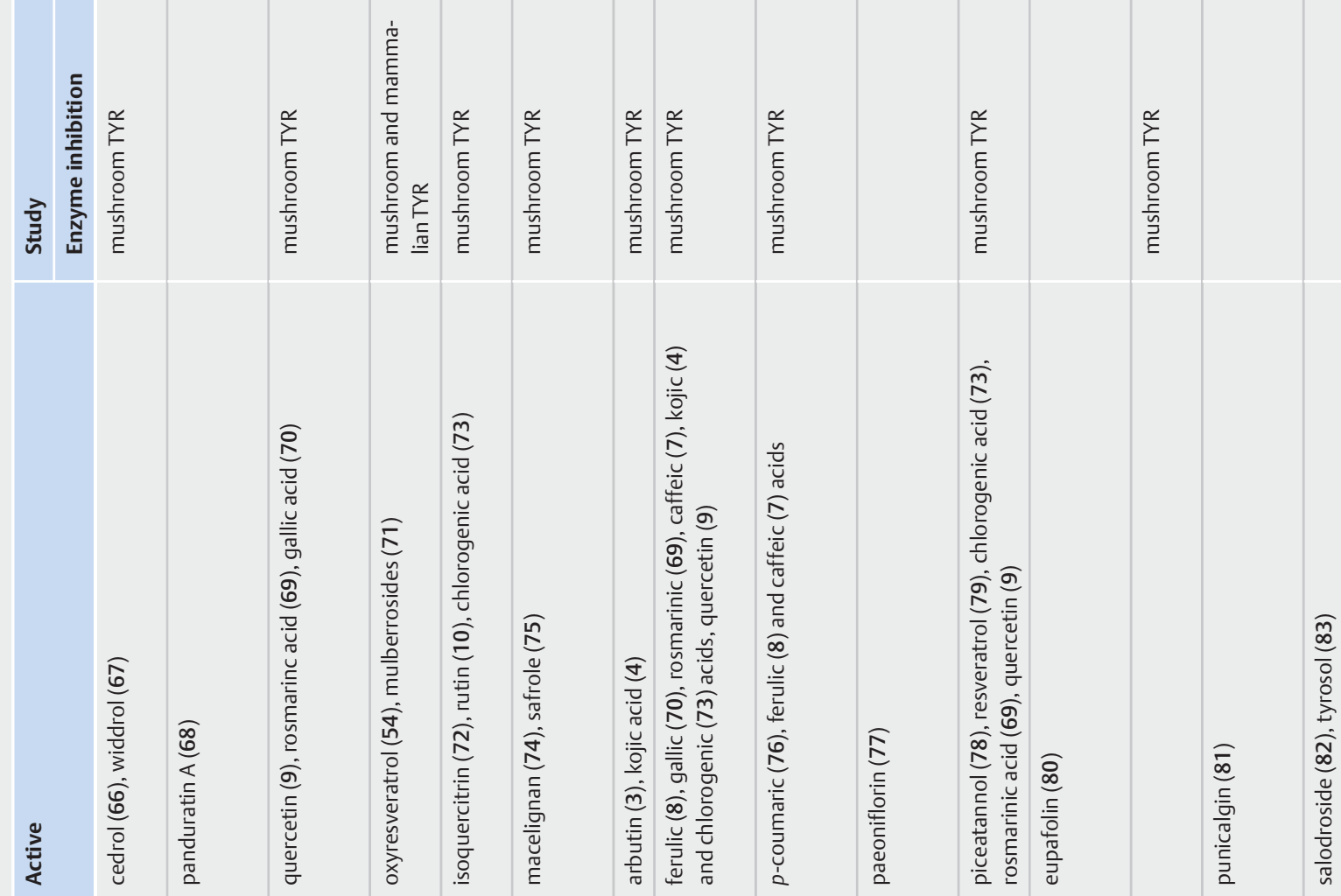

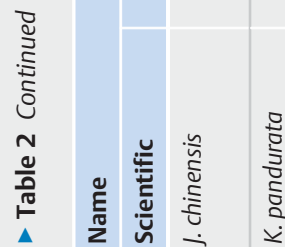
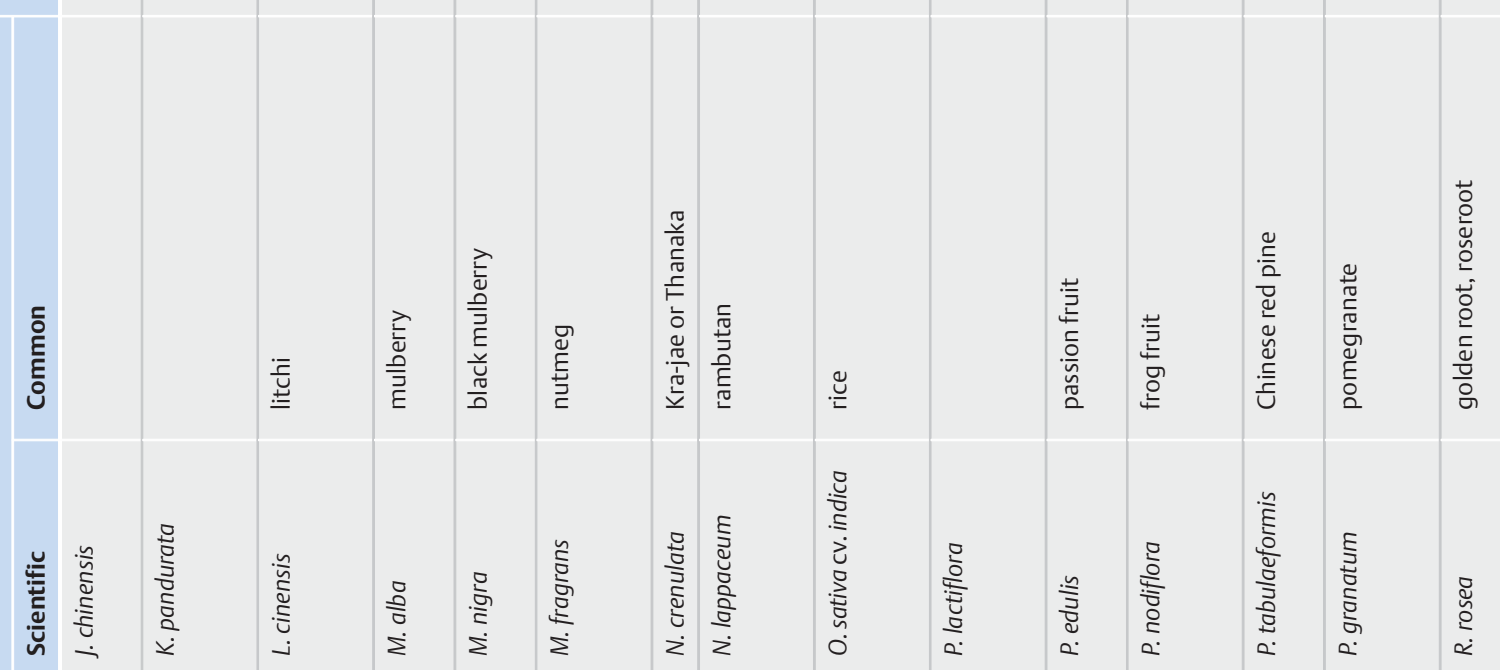


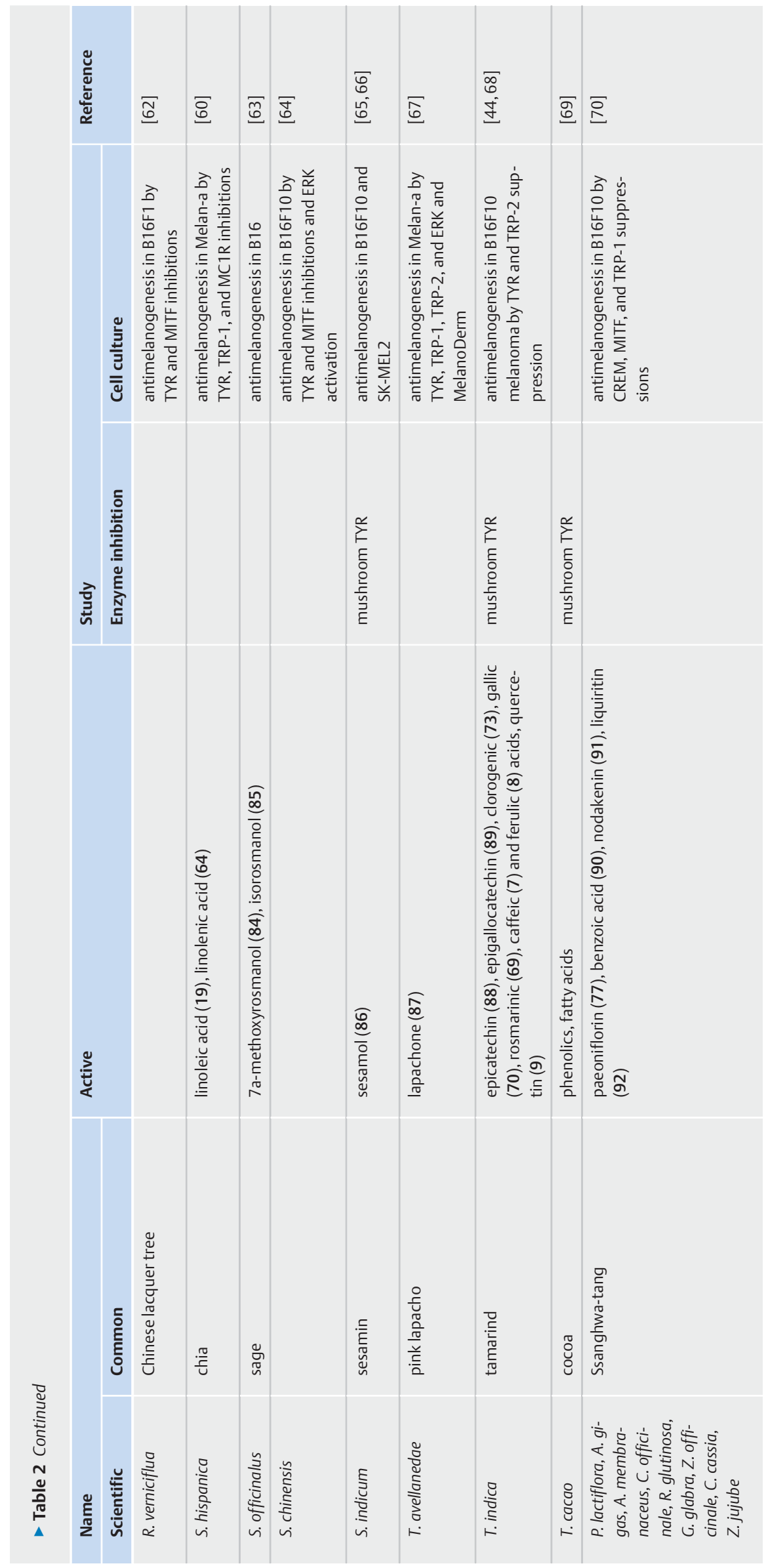




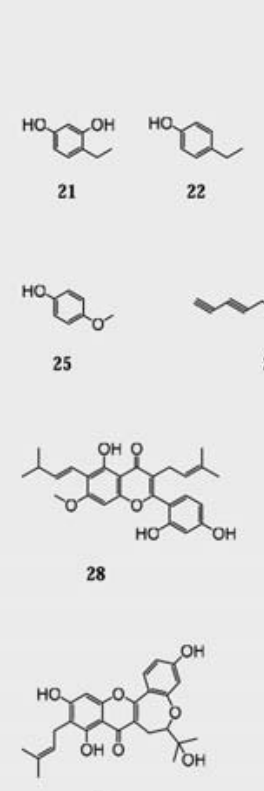

31

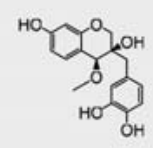

34

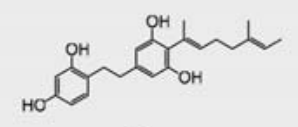

32

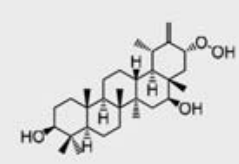

24

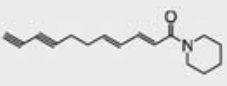

27

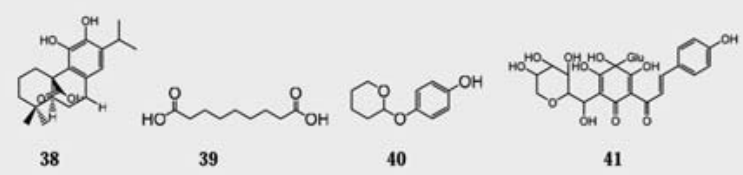

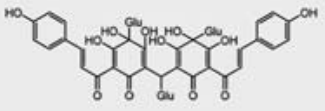

42

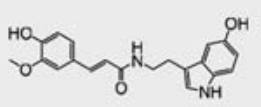

43

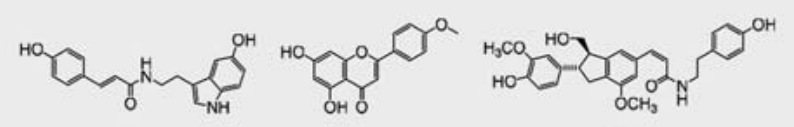

44

45

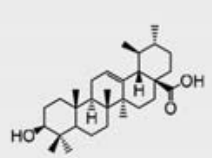

48

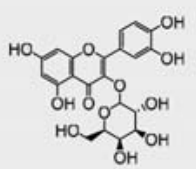

49

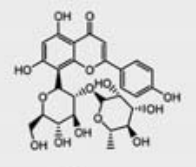

50

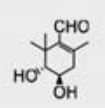

51

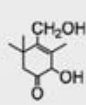

52

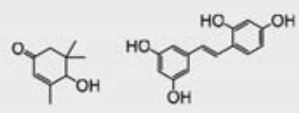

53
54
- Fig. 4 Chemical structures of the active ingredients isolated from A. sinensis, A. montana, A. dracunculus, Artrocarpus spp., and C. sappan.

(11.2\%), Rehmannia glutinosa (Gaertn.) Steud. (Orobanchaceae) (11.2\%), Glycyrrhiza glabra L. (Fabaceae) (8.4\%), Zingiber officinale Roscoe (Zingiberaceae) (4.4\%), Cinnamomum cassia Presl (Lauraceae) (8.4\%), and Zizyphus jujube Mill. (Rhamnaceae) (6.0\%), was refluxed in water for $3 \mathrm{~h}$ and then lyophilized to give a dried extract. The extract proved noncytotoxic toward B16F10 melanoma cells over a wide concentration range (up to $2 \mathrm{mg} / \mathrm{mL}$ ), and it suppressed cellular melanin production (to $70 \%$ and $45 \%$ of the initial level at 250 and $500 \mu \mathrm{g} / \mathrm{mL}$, respectively). At these concentrations, TYR activity was decreased by $17 \%$ and $36 \%$, respectively, with the mode of action involving CREB and MITF activities (including TRP-1). HPLC analysis revealed paeoniflorin (77) as the key active agent $(1.136 \mu \mathrm{M})$, followed by benzoic acid $(90)$, nodakenin (91), and liquiritin (92) $(0.415,0.130$, and $0.122 \mu \mathrm{M}$, respectively) [70].

- Table 2 summarizes the key properties and activities in relation to the botanical extracts and compounds described in this section. In addition, the isolated compounds are summarized as shown in > Figs. 4-8.
- Fig. 5 Chemical structures of the active ingredients isolated from C. longissima, C. tinctorius, C. crenata, C. antiquorum var. esculenta, C. azarolus, and C. sativus.

\section{Fungal Agents for Treating Skin Hyperpigmentation}

Fermentation of Alternaria alternata var. monosporus (Fr.) Keissl. (Pleosporaceae), a microorganism from the bark of the yew tree, provided alteronol (93). Alteronol (93) at concentrations $<2 \mu \mathrm{g} /$ $\mathrm{mL}$ is noncytotoxic toward B16F1 and B16F10 cells, although the compound suppressed cellular migration by $79.9 \%, 58.9 \%$, and 42.9\% (B16F1) and 63.3\%, 45.5\%, and 23.1\% (B16F10) at concentrations of $0.5,1$, and $1.5 \mu \mathrm{g} / \mathrm{mL}$, respectively [71].

Crude laccase isolated from Lentinus polychrous Lév. (Polyporaceae), having an enzymatic activity of $6.99 \mathrm{U} / \mathrm{mg}$ protein, was demonstrated to decolorize synthetic melanin on examination using PDA plates. High levels of melanin decolorization were observed at $\mathrm{pH}$ 4.5-6.5, with optimum bleaching (87\%) occurring within $5 \mathrm{~h}$ at $\mathrm{pH}$ 6.5. Enzymatic activity was enhanced in the presence of the synthetic radical ABTS and was the highest at $35^{\circ} \mathrm{C}$ $(77.5 \%)$, with higher temperatures $\left(60^{\circ} \mathrm{C}\right)$ resulting in suppression [72].

Monascus spp. Tiegh. (Elaphomycetaceae) produces an orange pigment that was further derivatized via exposure to an amino acid and amine in separate experiments to afford glutamic acid (94) 

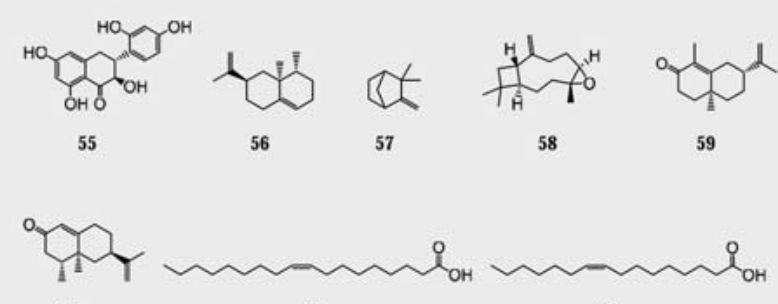

60

62

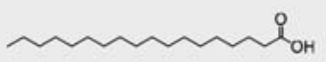

63

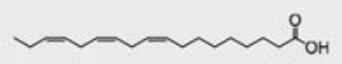

64

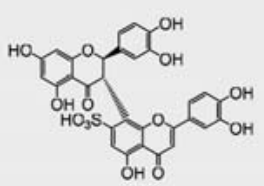

65
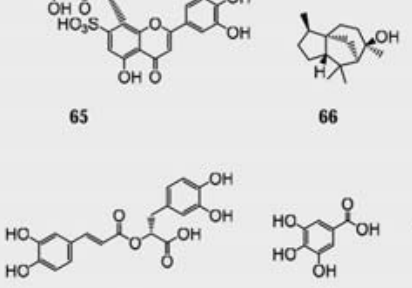

66

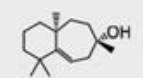

67

68

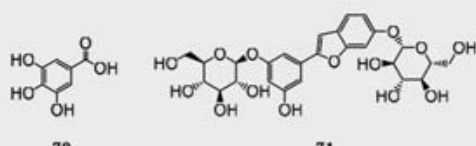<smiles>O=C(O)C1OC(C2CCC(O)CC2)C(O)C1=O</smiles>

72

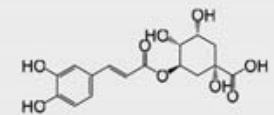

- Fig. 6 Chemical structures of the active ingredients isolated from C. rotundus, E. oleraceae, G. livingstonei, G. hederacea, J. chinensis, K. pandurate, L. chinensis, and M. alba.

and 1-amino-2-propanol (95), respectively, as characterized by HPLC and LC/MS. These modified compounds were highly active in B16F10 melanoma cells, exhibiting anti-TYR activity and suppressing TRP-1 and TRP-2 expression over concentration ranges

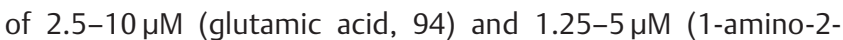
propanol, 95) [72, 73]. The fungus Monascus purpureus Went (Elaphomycetaceae) in the form of red rice yeast (angkak), or red koji, is traditionally used in eastern Asia as a food colorant and medicine. The extract obtained from sonicating angkak powder in water was subjected to chromatography to separate active principles. The extract inhibited mushroom TYR, albeit less potently than kojic (4) and ascorbic (2) acids $\left(\mathrm{IC}_{50}=5.57,5.00 \times 10^{-3}\right.$ and $5.00 \times 10^{-2} \mathrm{mg} / \mathrm{mL}$, respectively) [74].

Fungi with extracts exhibiting potential as skin-whitening agents and their activities are summarized in $\mathbf{~ T a b l e ~} \mathbf{3}$ as well as the isolated pure compounds as shown in $\bullet \mathbf{F i g . ~} \mathbf{8}$.<smiles>COC1CC(O)CC(CC(C)C(C)CC2CC3CCCC(C2)O3)C1</smiles>

74

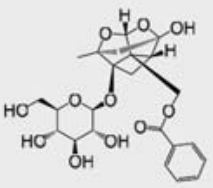

77

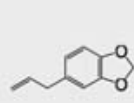

75

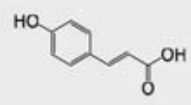

76

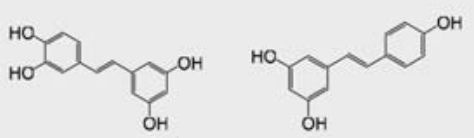

78

79

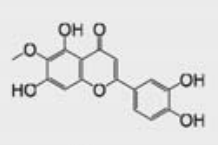

80

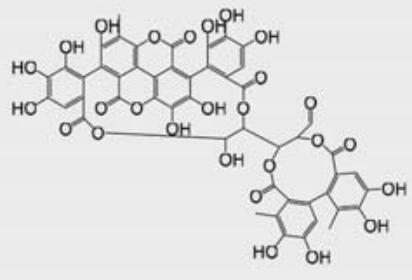

81

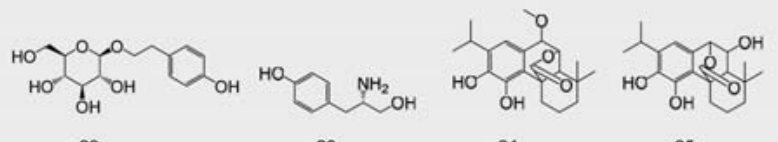

82

84

- Fig. 7 Chemical structures of the active ingredients isolated from M. fragrans, O. sativa cv. indica, P. lactiflora, P. edulis, P. nodiflora, P. granatum, $R$. rosea, and $S$. officinalis.

\section{Marine Algae for Skin Hyperpigmentation Treatment}

The $80 \%$ methanolic extract of Ishige foliacea Okamura (Ishigeaceae) on partitioning with EtOAc and chromatography afforded pure octaphlorethol A (96), which proved noncytotoxic toward B16F10 melanoma cells over a concentration range of 12.5$50 \mu \mathrm{M}$. TYR activity was significantly $(\mathrm{p}<0.05)$ suppressed in concert with reduced melanin content. The active compound also suppressed MITF expression and reduced p38 phosphorylation, while significantly enhancing ERK and JNK phosphorylation [75].

Sargassum polycystum C. Agardh (Sargassaceae), an edible brown seaweed, was extracted with $\mathrm{EtOH}$, and the extract was further fractionated with hexane and EtOAc. Mushroom TYR inhibitory assays of these fractions $(100 \mu \mathrm{g} / \mathrm{mL})$ indicated that the hexane fraction was the most potent, followed by the crude extract and EtOAc fraction (activity $=97.10 \% \pm 0.55 \%, 97.78 \%$ $\pm 1.34 \%$, and $100.58 \% \pm 1.81 \%$, respectively). All of these agents were less potent than kojic acid at the same concentration $(11.73 \% \pm 1.51 \%)$. Cytotoxicity and cellular TYR activity studies using B16F10 melanoma cells illustrated that the hexane fraction 

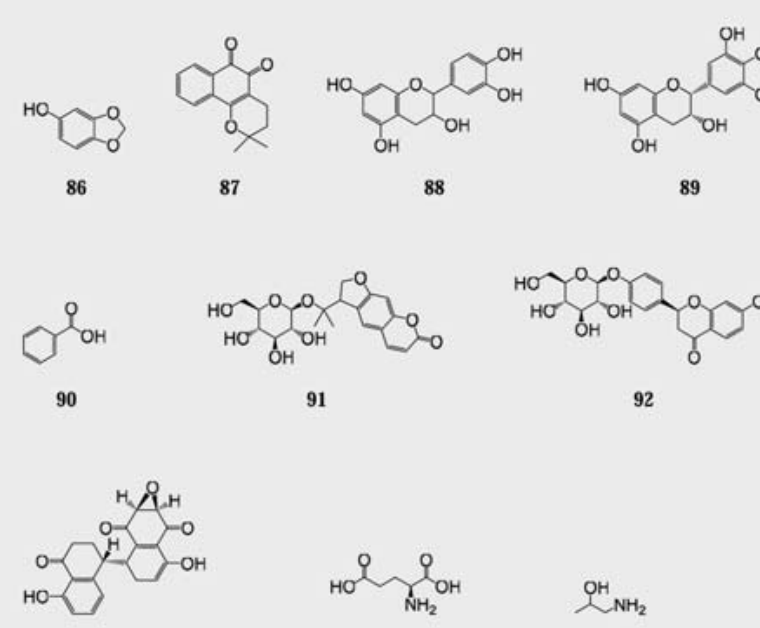

93
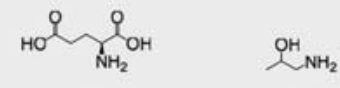

94

95

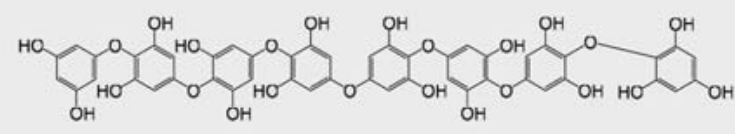

96

- Fig. 8 Chemical structures of the active ingredients isolated from S. indicum, T. avellanedae, $T$. indica, the herbal cocktail Sanghwatang, A. alternata var. monosporus, Monascus spp., and $I$. foliace.

possesses superior effects regarding noncytotoxicity and enzyme suppression ( $96.38 \% \pm 4.77 \%$ and $79.25 \% \pm 2.99 \%$, respectively) over the crude extract $(86.99 \% \pm 3.48 \%$ and $86.86 \% \pm 2.35 \%$, respectively) and EtOAc fraction $(77.32 \% \pm 0.98 \%$ and $89.08 \%$ $\pm 3.07 \%$, respectively). Notably, the cell viability and enzymatic activity of kojic acid-treated cells were $92.70 \% \pm 1.63 \%$ and
$84.56 \% \pm 1.62 \%$, respectively. On further screening, the chemical constituents of the extract were identified as saponins, flavonoids, tannins, terpenoids, phenols, sugars, amino acids, and amines [76].

The EtOAc fraction obtained from partitioning ethanolic wakame (Undaria pinnatifida [Harvey] Suringar, Alariaceae) extract proved noncytotoxic toward B16F10 melanoma cells at concentrations of $25-31.25 \mu \mathrm{g} / \mathrm{mL}$. At these concentrations, cellular melanin content was decreased in a concentration-dependent manner, with the suppression of TYR and MITF expression being responsible for this effect [77].

A summary of marine algae and their potential utility in skin hyperpigmentation treatment, including the active compounds, is shown in $>$ Table 3 ( $\bullet$ Fig. 8 ).

\section{Conclusion}

The biological activities of natural products, including plants, fungi, and marine organisms, potentially useful for treating skin hyperpigmentation were summarized in this text. Those with confirmed safety and biological activities in cell cultures including the precise mechanism of actions as well as the characterized actives responsible for the activities are therefore firstly encouraged to be applied. According to the sufficient data for safety profile and quality control practice, which are mandatory for manufacturing of the natural products and topical products comprised with the plant extracts; plants and natural products that are therefore first priority recommended for use as the key ingredients for skin-whitening products are A. montana, A. dracunculus, Artocarpus spp., C. sappan, C. tinctorius, J. chinensis, K. pandurate, M. fragrans, P. nodiflora, $R$. rosea, $R$. verniciflua, S. indicum, and T. avellanedae. Furthermore, A. alternata var. monosporus and Monascus spp., and marine-sourced algae (i.e., I. foliacea) are highlighted as the potential candidates for skin hyperpigmentation treatment. Some of the plants and algae summarized in this

- Table 3 Biological activities and potential of fungus and marine algae extracts for skin hyperpigmentation treatment.

\begin{tabular}{|c|c|c|c|c|c|}
\hline \multicolumn{2}{|l|}{ Name } & \multirow[t]{2}{*}{ Active } & \multicolumn{2}{|l|}{ Study } & \multirow[t]{2}{*}{ Reference } \\
\hline Scientific & Common & & Enzyme inhibition & Cell culture & \\
\hline $\begin{array}{l}\text { A. alternata var. } \\
\text { monosporus }\end{array}$ & & alteronol (93) & & $\begin{array}{l}\text { antimelanogenesis in B16F1 } \\
\text { and B16F10 }\end{array}$ & [71] \\
\hline L. polychorus & & laccase & melanin decolorization & & [72] \\
\hline M. spp. & angkak & $\begin{array}{l}\text { glutamic acid (94), 1-amino- } \\
\text { 2-propanol (95) }\end{array}$ & mushroom TYR & $\begin{array}{l}\text { antimelanogenesis in B16F10 } \\
\text { by TYR, TRP-1, and TRP-2 } \\
\text { suppressions }\end{array}$ & {$[73,74]$} \\
\hline I. foliacea & & octaphlorethol A (96) & & $\begin{array}{l}\text { antimelanogenesis in B16F10 } \\
\text { by TYR, MITF, and p38 } \\
\text { suppressions, enhance ERK } \\
\text { and JNK }\end{array}$ & {$[75]$} \\
\hline S. polycystum & $\begin{array}{l}\text { sargassum } \\
\text { weed }\end{array}$ & $\begin{array}{l}\text { saponins, flavonoids, tannins, } \\
\text { terpenoids, phenolics, } \\
\text { sugars, amino acids, amines }\end{array}$ & mushroom TYR & $\begin{array}{l}\text { antimelanogenesis in B16F10 } \\
\text { by anti-TYR }\end{array}$ & {$[76]$} \\
\hline U. pinnatifida & wakame & & & $\begin{array}{l}\text { antimelanogenesis in B16F10 } \\
\text { by TYR and MITF suppressions }\end{array}$ & [77] \\
\hline
\end{tabular}


- Table 4 Commercializing herbal extracts for skin hyperpigmentation treatment.

\begin{tabular}{|c|c|c|c|}
\hline Herbs/INCI name & Trade name & Supplier & Use level (\%) \\
\hline \multirow[t]{2}{*}{ A. millefolium } & Alpaflor Gigawhite & DSM & \\
\hline & Vegewhite & Sensient Cosmetic & \\
\hline \multirow[t]{4}{*}{ A. chinensis fruit } & Botanykem Kiwifruit & Berkem & \\
\hline & Synerlight 2 & Gattefossé & $0.5-3$ \\
\hline & Gatuline Spot-Light & & 3 \\
\hline & Morechem Kiwi Extract & Morecherm & \\
\hline A. polygama fruit & Nikkol Silver Vine Extract BG30 & Nikkol & \\
\hline A. vulgaris & Alpaflor Gigawhite & DSM & \\
\hline A. speciosa leaf & Nikkol Alpinia Leaf Extract BG & Nikkol & \\
\hline A. paniculata leaf & Actives International ViaPure Andrographis & Actives International & $0.1-0.2$ \\
\hline A. polymorpha root & QS anti-inflammatory formula & Fenchem & \\
\hline \multirow[t]{2}{*}{ A. uva-ursi } & Herbalia Bearberry & BASF & \\
\hline & Vegewhite & Sensient Cosmetic & \\
\hline \multirow[t]{5}{*}{ A. uva ursi leaf } & Bearberry Extract & Carrubba & \\
\hline & Melfade J & DSM & $1-8$ \\
\hline & Bearberry Dry Extract Uva Ursi 20\% & GfN-Selco & $0.3-1$ \\
\hline & Depigmentation Factor $2 \mathrm{U}$ & Lipoid Kosmetik & \\
\hline & Etioline & Sederma (Croda International Group) & \\
\hline A. catechu seed & Areca Catechu Extract & Bioland & $1-3$ \\
\hline A. capillaris & Nikkol Botanical Extract Complex B & Nikkol & \\
\hline A. heterophyllus seed & Whitessence & Lucas Meyer Cosmetics & $0.5-2$ \\
\hline B. roxburghii seed & Lightime Be & Ephyla & 1 \\
\hline B. vulgaris & Morechem Bamboo Extract & Morechem & \\
\hline B. perennis flower & Belides NP & CLR Berlin & $2-5$ \\
\hline B. pilosa & Revinage & Chemyunion Quimica & $1-2$ \\
\hline B. napus seedcake & Achromaxyl ISR biofunctional & Ashland Specialty Chemical & \\
\hline B. pekinensis root & VITA GENESIS WHITE & Vitalab & 0.5 \\
\hline B. papyrifera bark & Paper Mulberry Extract & Carruba & \\
\hline C. vulgaris & Vegewhite & Sensient Cosmetic & \\
\hline C. sinensis & Herbalia Green Tea & BASF & \\
\hline C. sinensis leaf & Green OL & Morechem & \\
\hline C. tinctorius bud & Natural TSC & Natural Solution & \\
\hline C. papaya & Actipone Green Papaya GW & Symrise & \\
\hline C. aurantium flower & ORGANIC ORANGE BLOSSOM DISTILLATE & Biocosmethic & \\
\hline C. aurantium fruit & Orange Extract & Morechem & \\
\hline C. limon fruit & Flashwhite Unispheres & Induchem & $0.5-2$ \\
\hline C. paradisi fruit/seed & FULL BRIGHT EX. & Morlab & $2-3$ \\
\hline C. unshiu fruit & Mandarin Extract & Morechem & \\
\hline C. armoracia root & Actiphyte Horseradish & Active Organics & $5-10$ \\
\hline C. arabica seed & GREEN COFFEA VITA & Vitalab & 0.5 \\
\hline C. sativus & Extrapone Saffron & Symrise & \\
\hline C. sativus & Flashwhite Unispheres & Induchem & $0.5-2$ \\
\hline C. longa & BioNatural Tumeric Root & BioOrganic Concepts & \\
\hline C. rotundus & Actipone Nutgrass (Motha) Root GW & Symrise & \\
\hline D. villosa root & Herbex Wild Yam Extract & Biospectrum & \\
\hline D. carota root & FULLBRIGHT EX. & Morlab & continued \\
\hline
\end{tabular}


- Table 4 Continued

\begin{tabular}{|c|c|c|c|}
\hline Herbs/INCI name & Trade name & Supplier & Use level (\%) \\
\hline E. euineensis & Revinage & Chemyunion Quimica & $1-2$ \\
\hline E. canadensis flower & Jeju Cana & Biospectrum & \\
\hline E. elatior flower & Ginger Torch & Naturex & \\
\hline F. foetida root & NAB Asafetida Extract & Lonza & \\
\hline G. hederacea & ActivGH & ActivON & \\
\hline \multirow[t]{10}{*}{ G. glabra root } & BIO-OSLP & Bioland & $0.05-0.2$ \\
\hline & Bio-SWF & Bioland & $0.5-1$ \\
\hline & Herbex Licorice Extract & Biospectrum & \\
\hline & PHYTODERMINA WHITENING & I. R. A. Istituto Ricerche & $5-10$ \\
\hline & Nikkol Botanical Extract Complex B & Nikkol & \\
\hline & Nikkol Polyol Soluble Licorice Extract & Nikkol & \\
\hline & Nikkol Aqua Licorice & Nikkol & \\
\hline & Vegewhite & Sensient Cosmetic & \\
\hline & SMACTIV & SMA Collaboratives & \\
\hline & Whitesphere Premium XP & Soliance & \\
\hline G. herbaceum seed & Revinage & Chemyunion Quimica & $1-2$ \\
\hline H. sabdariffa flower & Hibiscus Exfoliator & Lessonia & \\
\hline H. rhamnoides & Actipone Sea Buckthorn GW & Symrise & \\
\hline H. lupulus & Wonderlight & Sederma (Croda International Group) & 3 \\
\hline I. britannica flower & Morechem Elecampane Extract & Morechem & \\
\hline L. sibirica wood & SIBWHITE & Biocosmethic & \\
\hline \multirow[t]{2}{*}{ L. sativum sprout } & SulforaWhite & Mibelle Biochemistry & $2-5$ \\
\hline & Delentigo & Mibelle Biochemistry & $2-6$ \\
\hline L. usitatissimum seed & Revinage & Chemyunion Quimica & $1-2$ \\
\hline L. citriodora & Allplant Essence Organic Verbena & Symrise & \\
\hline L. chinense fruit & Morechem Goji Berry Extract & Morechem & \\
\hline M. officinalis & Extrapone Magnolia GW & Symrise & \\
\hline M. officinalis bark & QS anti-inflammatory formula & Fenchem & \\
\hline M. sylvestris & Alpaflor Gigawhite & DSM & \\
\hline M. indica fruit & Melan'oWhite & ID bio & \\
\hline M. officinalis leaf & Alpaflor Gigawhite & DSM & \\
\hline M. aquatica & Extrapone Watermint $\mathrm{P}$ & Symrise & \\
\hline M. piperita leaf & Alpaflor Gigawhite & DSM & \\
\hline M. scaber & Etioline & Sederma (Croda International Group) & \\
\hline \multirow[t]{4}{*}{ M. alba root } & Cosme-Phytami Mulberry (white) tree & Alban Muller International & \\
\hline & Bio-SWF & Bioland & $0.5-1$ \\
\hline & Nikkol Botanical Extract Complex B & Nikkol & \\
\hline & Perperse Incorporated-Mulberry Root Extract & Persperse & $0.5-1$ \\
\hline M. alba leaf & Herbex Mullberry Extract & Biospectrum & \\
\hline M. alba fruit & FULL BRIGHT EX. & Morlab & $2-3$ \\
\hline M. dubia fruit & CAMU-CAMU VITANEYC & Neyber & \\
\hline N. alba flower & Sepicalm VG & Seppic & \\
\hline O. europaea leaf & ILLUMISCIN & Rahn & $3-7$ \\
\hline O. vulgare & Allplant Essence Organic Oregano & Symrise & \\
\hline P. erosus & Actipone Bengkoang & Symrise & \\
\hline P. suffruticosa bark & Peony Root Extract & Morechem & \\
\hline
\end{tabular}


- Table 4 Continued

\begin{tabular}{|c|c|c|c|}
\hline Herbs/INCI name & Trade name & Supplier & Use level (\%) \\
\hline P. maritimum & Neurolight.61 G & Codif & 1.5 \\
\hline P. tectorius fruit & Pandanas (wild pinneapple) & Lucas Meyer Cosmetics & \\
\hline P. densiflora pollen & Pine Pollen Extract & Morechem & \\
\hline P. sativum & Actiwhite LS 9808 & Laboratoires Serobiologiques & $2-3$ \\
\hline P. tenax flower & Jeju Lily & Biospectrum & \\
\hline P. emblica fruit & Premier Amla Super & Premier Specialties & \\
\hline P. lanceolata leaf & Senestem & Sederma (Croda International Group) & \\
\hline P. cuspidatum & Herbex Resverol 0.5 Extract & Biospectrum & \\
\hline P. veris & Alpaflor Gigawhite & DSM & \\
\hline P. persica leaf & Bio-SWF & Bioland & $0.5-1$ \\
\hline P. granatum & Herbex Pomegranate Extract & Biospectrum & \\
\hline P. granatum flower & Pomegranate flower & Naturex & \\
\hline R. rhaponticum root & Unilucent PA-13 & Induchem & $0.5-1$ \\
\hline R. officinalis leaf & Herbex Rosemary Extract & Biospectrum & \\
\hline R. occidentalis & Tyrostat & Lucas Meyer Cosmetics & $1-3$ \\
\hline S. chinensis & Saururus Chinensis Extract & Morechem & \\
\hline \multirow[t]{2}{*}{ S. baicalensis root } & Nikkol Botanical Extract Complex B & Nikkol & \\
\hline & Vegewhite & Sensient Cosmetic & \\
\hline S. angustifolia root & Synerlight 2 & Gattefossé & $0.5-3$ \\
\hline S. flavescens root & Gatuline Spot-Light & Gattefossé & 3 \\
\hline S. japonica & Vegewhite & Sensient Cosmetic & \\
\hline T. officinale & Extrapone Dandelion & Symrise & \\
\hline T. chebula & Ellagic Acid & Sabinsa & \\
\hline T. aestivum & Axolight & Soliance & \\
\hline T. pratense & NioSkin RCL40 & Linnea & \\
\hline V. officinalis & Alpaflor Gigawhite & DSM & \\
\hline Z. jujuba fruit & Nikkol Botanical Extract Complex B & Nikkol & \\
\hline
\end{tabular}

- Table 5 Commercializing microorganism extracts for skin hyperpigmentation treatment.

\begin{tabular}{|l|l|l|l|}
\hline Microorganism/INCI name & Trade name & Supplier & Use level (\%) \\
\hline Aspergillus sp. & PHYTODERMINA WHITENING & I.R. A. Istituto Ricerche & 5 -10 \\
\hline D. membranacea & 3M3.WHITERIS G & Codif & 3 \\
\hline H. fusiforme & Hijiki Extract & Morechem & BASF \\
\hline L. digitata & Seanergilium BG & Biospectrum \\
\hline L. edodes & Herbex Shiidake Extract & Actives International \\
\hline P. sajor-caju & ViaFerm White & Gelyma \\
\hline U. pinnatifida & KIMARINE & \\
\hline & OROSEA & \\
\hline & PHYACTYL & Naturactiva \\
\hline & Wakamine 1\% & \\
\hline & Wakamine XP & \\
\hline & Wakamine & Soliance \\
\hline
\end{tabular}


group are of economic importance; thus, there is therefore less risk of availability lacking, and some of them are commercialized offerings are detailed in $\mathbf{r}$ Tables $\mathbf{4}$ and $\mathbf{5}$. This information would meet the interests of cosmetic and formulation chemists in natural product applications. However, precise mechanisms of action remain unclear in some commercializing ones. Furthermore, screening with in vitro assays is still recommended for inclusion of the natural products assessment in cell culture prior to evaluation in human skin models and human skin, respectively, although the in vitro results are in contrast with the cell culture and skin model in some cases as per se there are some differences in in vitro mediums and ex vivo that is more similar to the in vivo study [3]. Medicinal plant researchers will have an interest in the presented data. They are therefore encouraged to fill in the gap of some unclear issues in an order to strengthen and widen application of plants and natural extracts for pharmaceutical and cosmetic industries. In addition to the priority plants and marine algae listed above, the rest are potentially challenging to examine due to their precise safety and the mechanism and characterization of their biological activities.

\section{Acknowledgements}

Mae Fah Luang University is acknowledged regarding facility support during the preparation of this manuscript. The reviewers are acknowledged for their valuable suggestions to make the article more comprehensive.

Conflict of Interest

The authors have no conflicts of interest to declare.

\section{References}

[1] Kanlayavattanakul M, Lourith N. Skin hyperpigmentation treatment using herbs: a review of clinical evidences. J Cosmet Laser Ther 2017. doi:10.1080/14764172.2017.1368666

[2] Kanlayavattanakul M, Lourith N. Therapeutic agents and herbs in topical application for acne treatment. Int J Cosmet Sci 2011; 33: 289-297

[3] Kanlayavattanakul M, Lourith N. An update on cutaneous aging treatment using herbs. J Cosmet Laser Ther 2015; 17: 343-352

[4] Lourith N, Kanlayavattanakul M. Hair loss and herbs for treatment. J Cosmet Dermatol 2013; 12: 210-222

[5] Ong MWS, Maibach HI. Skin whitening Agents. In: Barel AO, Paye M, Maibach HI, eds. Handbook of cosmetic Science and Technology, 4th ed. New York: CRC; 2014: 423-438

[6] Shin JW, Park KC. Current clinical use of depigmenting agents. Dermatol Sin 2014; 32: 205-210

[7] Michihara A, Morita S, Kirokawa Y, Ago S, Akasaki K, Tsuji H. Delta-tocotrienol causes decrease of melanin content in mouse melanoma cells. J Health Sci 2009; 55: 314-318

[8] Michihara A, Ogawa S, Kamizaki Y, Akasaki K. Effect of delta-tocotrienol on melanin content and enzymes for melanin synthesis in mouse melanoma cells. Biol Pharm Bull 2010; 33: 1471-1476

[9] Ng LT, Lin LT, Chen CL, Chen HW, Wu S], Lin CC. Anti-melanogenic effects of $\delta$-tocotrienol are associated with tyrosinase-related proteins and MAPK signaling pathway in B16 melanoma cells. Phytomed 2014; 21: $978-983$
[10] Chaiprasongsuk A, Onkoksoong T, Pluemsamran T, Limsaengurai S, Panich U. Photoprotection by dietary phenolics against melanonogenesis induced by UVA through Nrf2-dependent antioxidant responses. Redox Biol 2016; 8: 79-90

[11] Chung TW, Kim S], Choi HK, Kwak CH, Song KH, Suh SJ, Kim K], Ha KT, Park YG, Chang YC, Chang HW, Lee YC, Kim CH. CAPE suppresses VEGFR-2 activation, and tumor neovascularization and growth. J Mol Med 2013; 91: 271-282

[12] Lee JY, Choi H], Chung TW, Kim CH, Jeong HS, Ha KT. Caffeic acid phenethyl ester inhibits alpha-melanocyte stimulating hormone-induced melanin synthesis through suppressing transactivation activity of mucrophthalmia-associated transcription factor. J Nat Prod 2013; 76: 1399-1405

[13] Bauzaiene NN, Chaabane F, Sassi A, Chekir-Ghedira L, Ghedira K. Effect of apigenin-7-glucoside, genkwanin and naringenin on tyrosinase activity and melanin synthesis in B16F10 melanoma cells. Life Sci 2016; 144: 80-85

[14] Sakuma K, Ogawa M, Sugibayashi K, Yamada KI, Yamamoto K. Relationship between tyrosinase inhibitory action and oxidation-reduction potential of cosmetic whitening ingredients and phenol derivatives. Arch Pharm Res 1999; 22: 335-339

[15] Kim DS, Park SH, Kwon SB, Li K, Youn SW, Park KC. (-)-Epigallocatechin3-gallate and hinokitiol reduce melanin synthesis via decreased MITF production. Arch Pharm Res 2004; 27: 334-339

[16] Sasaki M, Kondo M, Sato K, Umeda M, Kawabata K, Takahashi Y, Suzuki $\mathrm{T}$, Matsumaga $\mathrm{K}$, Inoue S. Rhododendrol, a depigmentation-inducing phenolic compound, excerts melanocyte cytotoxicity via a tyrosinasedependent mechanism. Pigment Cell Melanoma Res 2014; 27: 754-763

[17] Ando H, Funasaka Y, Oka M, Ohashi A, Furumura M, Matsunaga J, Matsunaga N, Hearing VJ, Ichihashi M. Possible involvement of proteolytic degradation of tyrosinase in the regulatory effect of fatty acids on melanogenesis. J Lipid Res 1999; 40: 1312-1316

[18] Ando H, Watabe H, Valencia JC, Yasumoto K, Furumura M, Funasaka Y Oka M, Ichihashi M, Hearing VJ. Fatty acids regulate pigmentation via proteasomal degradation of tyrosinase. J Biol Chem 2004; 279: 1542715433

[19] Lam RYY, Lin ZX, Sviderskaya E, Cheng CHK. Application of a combined sulphorhodamine $B$ and melanin assay to the evaluation of Chinese medicines and their constituent compounds for hyperpigmentation treatment. J Ethnopharmacol 2010; 132: 274-279

[20] Maeda K, Naitou T, Umishio K, Fukuhara T, Motoyama A. A novel melanin inhibitor: hydroperoxy traxastane-type triterpene from flowers of Arnica montana. Biol Pharm Bull 2007; 30: 873-879

[21] Yamada M, Nakamura K, Watabe T, Ohno O, Kawagoshi M, Maru N Uotsu N, Chiba T, Yamaguchi K, Uemura D. Melanin biosynthesis inhibitors from tarragon Artemisia dracunculus. Biosci Biotechnol Biochem 2011; 75: 1628-1630

[22] Dej-Adisai S, Meechai I, Puripattanavong J, Kummee S. Antityrosinase and antimicrobial activities from Thai medicinal plants. Arch Pharm Res 2014; 37: 473-483

[23] Jin Y], Lin CC, Lu TM, Li JH, Chen IS, Kuo YH, Ko HH. Chemical constituents derived from Artocarpus xanthocarpus as inhibitors of melanin biosynthesis. Phytochem 2015; 117: 424-435

[24] Arung ET, Shimizu K, Kondo R. Inhibitory effect of artocarpanone from Artocarpus heterophyllus on melanin biosynthesis. Biol Pharm Bull 2006; 29: 1966-1969

[25] Germanò MP, Cacciola F, Donato P, Dugo P, Certo G, D’Angelo V, Mondello L, Rapisarda A. Betula pendula leaves: polyphenolic characterization and potential innovative use in skin whitening products. Fitoterapia 2012; 83: 877-882

[26] Mitani K, Takano F, Kawabata T, Allam AE, Ota M, Takahashi T, Yahagi N, Sakurada C, Fushiya S, Ohta T. Suppression of melanin synthesis by the phenolic constituents of sappanwood (Caesalpinia sappan). Planta Med 2013; 79: 37-44 
[27] Yamahara M, Sugimura K, Kumagai A, Fuchino H, Kuroi A, Kagawa M, Itoh $\mathrm{Y}$, Kawahara $\mathrm{H}$, Nagaoka $\mathrm{Y}$, lida O, Kawahara N, Takemori $\mathrm{H}$, Watanabe H. Callicarpa longissima extract, carnosol-rich, potently inhibits melanogenesis in B16F10 melanoma cells. J Nat Med 2016; 70: 28-35

[28] Chen YS, Lee SM, Lin CC, Liu CY, Wu MC, Shi WL. Kinetic study on the tyrosinase and melanin formation inhibitory activities of carthamus yellow isolated from Carthamus tinctorius L. J Biosci Bioeng 2013; 115: 242245

[29] Roh JS, Han JY, Kim JH, Hwang JK. Inhibitory effects of active compounds isolated from safflower (Carthamus tinctorius L.) seeds for melanogenesis. Biol Pharm Bull 2004; 27: 1976-1978

[30] Kim JH, Choi GN, Kwak JH, Jeong CH, Jeong HR, Lee U, Kim M], Heo H]. Inhibitory effects of chestnut inner skin extracts on melanogenesis. Food Sci Biotechnol 2012; 21: 1571-1576

[31] Graf BL, Cheng DM, Esposito D, Shertel T, Poulev A, Plundrich N, Itenberg D, Dayan N, Lila MA, Raskin I. Compounds leached from quinoa seeds inhibit matrix metalloproteinase activity and intracellular reactive oxygen species. Int J Cosmet Sci 2015; 37: 212-221

[32] Silveira JEPS, del Pereda MCW, Eberlin S, Dieamant GC, Di Stasi LC. Effects of Coccoloba uvifera L. on UV-stimulated melanocytes. Photodermatol Photoimmunol Photomed 2008; 24: 308-313

[33] Kim KH, Moon EM, Kim SY, Lee KR. Lignans from the tuber-barks of Colocasia antiquorum var. esculenta and their antimelanogenic activity. J Agric Food Chem 2010; 58: 4779-4785

[34] Mustapha N, Bzéouich IM, Ghedira K, Hennebelle T, Chekir-Ghe-Dira L. Compounds isolated from the aerial part of Crataeues azarolus inhibit growth of B16F10 melanoma cells and exert a potent inhibition of the melanin synthesis. Biomed Pharmacother 2015; 69: 139-144

[35] Li CY, Lee E], Wu TS. Antityrosinase principles and constituents of the petals of Crocus sativus. J Nat Prod 2004; 67: 437-440

[36] Hu S, Zheng Z, Chen F, Wang M. Activity and mechanism of natural resorcinol-type phenolics from the twigs of Curdrania tricuspidata as skin whitening agents. IFSCC Mag 2014; 17: 3-5

[37] Nam JH, Nam DY, Lee DU. Valencene from the rhizomes of Cyperus rotundus inhibits skin photoaging-related ion channels and UV-induced melanogenesis in B16F10 melanoma cells. J Nat Prod 2016; 79: 1091-1096

[38] Teixeira RDS, Rocho PR, Polonini HC, Antônio M, Brandão F, Chaves MDGAM, Raposo NRB. Mushroom tyrosinase inhibitory activity and major fatty acid constituents of Amazonian native flora oils. Braz J Pharm Sci 2012; 48: 399-404

[39] Mulholland DA, Mwangi EM, Dlova NC, Plant N, Crouch NR, Coombes $\mathrm{PH}$. Non-toxic melanin production inhibitors from Gracinia livingstonei (Clusiaceae). J Ethnopharmacol 2013; 149: 570-575

[40] Qiao Z, Koizumi Y, Zhang M, Natsui M, Flores M], Gao L, Yusa K, Koyota S, Sugiyama T. Anti-melanogenesis effect of Glechoma hederacea L. extract on B16 murine melanoma cells. Biosci Biotechnol Biochem 2012; 76: 1877-1883

[41] Jin KS, Lee JY, Hyun SK, Kim BW, Kwon HJ. Juniperus chinensis and the functional compounds, cedrol and widdrol, ameliorate $\alpha$-melanocyte stimulating hormone-induced melanin formation in B16F10 cells. Food Sci Biotechnol 2015; 24: 611-618

[42] Lee CW, Kim HS, Kim HK, Kim JW, Yoon JH, Cho Y, Hwang JK. Inhibitory effect of panduratin A isolated from Kaempferia panduarata Roxb. on melanin biosynthesis. Phytother Res 2010; 24: 1600-1604

[43] Kanlayavattanakul M, Ospondpant D, Raktanonchai U, Lourith N. Biological activity assessment and phenolic compounds characterization from the fruit pericarp of Litchi chinensis for cosmetic application. Pharm Biol 2012; 50: 1384-1390

[44] Lourith N, Kanlayavattanakul M, Chaikul P. Chansriniyom C, Bunwatcharaphansakun P. In vitro and cellular activities of the selected fruits residues for skin aging treatment. An Acad Bras Ciênc 2017; 89: 577-589
[45] Lee SH, Choi SY, Kim H, Hwang JS, Lee BG, Gao J], Kim SY. Mulberroside F isolated from the leaves of Morus alba inhibits melanin biosynthesis. Biol Pharm Bull 2002; 25: 1045-1048

[46] de Freitas MM, Fontes PR, Souza PM, Fagg CW, da Silva Guerra EN, de Medeiros Nóbrega YK, Silveira D, Fonseca-Bazzo Y, Simeoni LA, Homem-de-Mello M, Magalhães PO. Extracts of Morus nigra L. leaves standardized in chlorogenic acid, rutin and isoquercitrin: tyrosinase inhibition and cytotoxicity. PLoS One 2016; 11: e0163130

[47] Cho Y, Kim KH, Shim JS, Hwang JK. Inhibitory effects of macelignan isolated from Myristica fragrans HOUTT. on melanin biosynthesis. Biol Pharm Bull 2008; 31: 986-989

[48] Cho S], Kwon HS. Tyrosinase inhibitory activities of safrole from Myristica fragrans Houtt. J Appl Biol Chem 2015; 58: 295-301

[49] Wangthong S, Palaga T, Rengpipat S, Wanichwecharungruang SP, Chanchaisak P, Heinrich M. Biological activities and safety of thanaka (Hesperethusa crenulata) stem bark. J Ethnopharmacol 2010; 132: 466472

[50] Lourith N, Kanlayavattanakul M, Pongpunyayuen S. Botanical Arbutin from Naringi crenulata. In: Hayes LM, ed. Cosmetics: Types, Allergies and Applications. New York: Nova; 2011: 157-164

[51] Lourith N, Kanlayavattanakul M, Pongpunyayuen S, Chaiwarith ]. Characterization of arbutin and kojic acid in Naringi crenulata. Household Pers. Care Today 2012; 7: 20-21

[52] Pongpunyayuen P, Lourith N. Radical scavenging activity and phenolic compounds in rambutan peels extracts. Paccon Conference 2011. Bangkok, Thailand; 2011

[53] Kanlayavattanakul M, Lourith N, Chaikul P. Jasmine rice panicle: a safe and efficient natural ingredient for skin aging treatments. J Ethnopharmacol 2016; 193: 607-616

[54] Qiu J, Chen M, Liu J, Huang X, Chen J, Zhou L, Ma J, Sextius P, Pena AM, Cai Z, Jeulin S. The skin-depigmenting potential of Paeonia lactiflora root extract and paeoniflorin: in vitro evaluation using reconstructed pigmented human epidermis. Int J Cosmet Sci 2016; 38: 444-451

[55] Matsui Y, Sugiyama K, Kamei M, Takahashi T, Suzuki T, Katagata Y, Ito T. Extract of passion fruit (Passiflora edulis) seed containing high amounts of piceatannol inhibits melanogenesis and promotes collagen synthesis. J Agric Food Chem 2010; 58: 11112-11118

[56] Lourith N, Kanlayavattanakul M. Antioxidant activities and phenolics of Passiflora edulis seed recovered from juice production residue. J Oleo Sci 2013; 62: 235-240

[57] Lourith N, Kanlayavattanakul M, Chingunpitak J. Development of sunscreen products containing passion fruit seed extract. Braz J Pharm Sci 2017; 53: e16116

[58] Ko HH, Chiang YC, Tsai MH, Liang C], Hsu LF, Li SY, Wang MC, Yen FL, Lee CW. Eupofalin, a skin whitening flavonoid isolated from Phyla nodiflora, downregulated melanogenesis: role of MAPK and Akt pathways. J Ethnopharmacol 2014; 151: 386-393

[59] Cho HR, Kang KA, Bhuiyan MIH, Oh MS, Lee MH, Kim Y]. Antimelanogenic effect of Pini Nodi Lignum extract in HM3KO melanoma cells. Mol Cell Toxicol 2011; 7: 135-139

[60] Diwakar G, Rana J, Saito L, Vredeveld D, Zemaitis D, Scholten J. Inhibitory effect of a novel combination of Salvia hispanica (chia) seed and Punica granatum (pomergranate) fruit extracts on melanin production. Fitoterapia 2014; 97: 164-171

[61] Chiang HM, Chien YC, Wu CH, Kuo YH, Wu WC, Pan YY, Su YH, Wen KC. Hydroalcoholic extract of Rhodiola rosea L. (Crassulaceae) and its hydrolysate inhibit melanogenesis in B16F0 cells by regulating the CREB/MITF tyrosinase pathway. Food Chem Toxicol 2014; 65: 129-139

[62] Kim SH, Seo HS, Jang BH, Shin YC, Ko SG. The effect of Rhunas vernififlua strokes (RVS) for anti-aging and whitening of skin. Orient Pharm Exp Med 2014; 14: 213-222 
[63] Sallam A, Mira A, Ashour A, Shimizu K. Acetylcholine esterase inhibitors and melanin synthesis inhibitors from Salvia officinalis. Phytomed 2016; 23: $1005-1011$

[64] Lee DH, Kim DH, Oh IY, Kim SY, Lim YY, Kim MH, Kim YH, Choi YM, Kim SE, Kim BJ, Kim MN. Inhibitory effects of Saururi chinensis extracts on melanin biosynthesis in B16F10 melanoma cells. Biol Pharm Bull 2013; 36: $772-779$

[65] Kumar CM, Sathisha UV, Dharmesh S, Rao AGA, Singh SA. Interaction of sesamol (3,4-methylenedioxyphenol) with tyrosinase and its effect on melanin synthesis. Biochime 2011; 93: 562-569

[66] Srisayam M, Weerapreeyakul N, Barusrux S, Kanokmedhakul K. Antioxidant, antimelanogenic, and skin-protective effect of sesamol. J Cosmet Sci 2014; 65: 69-79

[67] Kim JH, Lee SM, Myung CH, Lee KR, Hyun SM, Lee JE, Park YS, Jeon SR, Park JI, Chang SE, Hwang JS. Melanogenesis inhibition of $\beta$-lapachone, a natural product from Tabebuia avellanedae, with effective in vivo lightening potency. Arch Dermatol Res 2015; 307: 229-238

[68] Kanlayavattanakul M, Lourith N. Biologically active phenolics in seed coat of three sweet Tamarindus indica varieties grown in Thailand. Adv Sci Eng Med 2012; 4: 511-516

[69] Karim AA, Azlan A, Ismail A, Hashim P, Gani SSA, Zainudin BH, Abdullah NA. Phenolic composition, antioxidant, anti-wrinkles and tyrosinase inhibitory activities of cocoa pod extract. BMC Complement Altern Med 2014; 14: 381
[70] Kim A, Yim NH, Im M, Jung YP, Liang C, Cho WK, Ma JY. Ssanghwa-tang, an oriental herbal cocktail, exerts anti-melanogenic activity by suppression of the p38 MAPK and PKA signaling pathways in B16F10 cells. BMC Complement Altern Med 2013; 13: 214

[71] Wang Z, Wang D, Liu L, Guo D, Yu B, Zhang B, Han B, Sun X, Zheng Q. Alteronol inhibits the invasion and metastasis of B16F10 and B16F1 melanoma cells in vitro and in vivo. Life Sci 2014; 98: 31-38

[72] Khammuang S, Sarnthima R. Decolorization of synthetic melanin by crude laccases of Lentinus polychrous Lév. Folia Microbiol 2013; 58: 1-7

[73] Jo D, Choe D, Nam K, Shin CS. Biological evaluation of novel derivatives of the orange pigments from Monascus sp. as inhibitors of melanogenesis. Biotechnol Lett 2014; 36: 1605-1613

[74] Wu LC, Chen YC, Ho JAA, Yang CS. Inhibitory effect of red koji extracts on mushroom tyrosinase. J Agric Food Chem 2003; 51: 4240-4246

[75] Kim KN, Yang HM, Kang SM, Kim D, Ahn G, Jeon Y]. Octaphlorethol A isolated from Ishige foliacea inhibits $\alpha$-MSH-stimulated induced melanogenesis via ERK pathway in B16F10 melanoma cells. Food Chem Toxicol 2013; 59: 521-526

[76] Chan YY, Kim KH, Cheah SH. Inhibitory effects of Sargassum polycystum on tyrosinase activity and melanin formation in B16F10 murine melanoma cells. J Ethnopharmacol 2011; 137: 1183-1188

[77] Kim M], Kim DS, Yoon HS, Lee WJ, Lee NH, Hyun CG. Melanogenesis inhibitory activity of Korean Undaria pinnatifida in mouse B16 melanoma cells. Interdiscip Toxicol 2014; 7: 89-92 